\title{
An Investigation on Tolerance and Biosorption Potential of Aspergillus awamori ZU JQ 965830.1 to $\mathrm{Cu}(\mathrm{II})$
}

\author{
Manal T. El-Sayed \\ Botany Department, Faculty of Science, Zagazig University, \\ Zagazig, Egypt.
}

\begin{abstract}
THE MINIMUM inhibitory concentration (MIC) value of A.awamori for $\mathrm{Cu}(\mathrm{II})$ was $3100 \mathrm{mg} / \mathrm{l}$ and a complete inhibition of biomass production was observed at $800 \mathrm{mg} / \mathrm{l}$ concentration of $\mathrm{Cu}$ (II). Slight changes were observed by SEM investigation in $\mathrm{Cu}$ (II)-stressed biomass. Quantification of $\mathrm{Cu}$ (II) was performed by EDAX. Transmission electron microscopy investigation (TEM) confirmed the involvement of extracellular adsorption, intracellular penetration through the cell wall and vacuolation. $\mathrm{Cu}(\mathrm{II})$ stress induced noticeable changes in the activities of polyphenol oxidase(PPO), glutathione reductase (GR) and peroxidase (POD) and in the concentration of total antioxidant, soluble protein and thiol. High performance liquid chromatography analysis (HPLC) revealed that $\mathrm{Cu}$ (II) stress stimulated the production of oxalic acid .Maximum $\mathrm{Cu}$ (II) uptake capacity was achieved at $\mathrm{pH} 4.0$, initial metal ion concentration $500 \mathrm{mg} / \mathrm{l}$ and biomass dosage $1 \mathrm{~g} / \mathrm{l}$. Maximum $\mathrm{Cu}$ (II) uptake capacities were reached after $180 \mathrm{~min}$ for live biomass and $30 \mathrm{~min}$ for dead biomass. Fourier transform infrared spectroscopy (FTIR) results gave an indicateion of chelation between oxygen-, nitrogen-, phosphorus- and especially sulphur-containing ligands of biomass with metal ions. X-ray diffraction analysis (XRD) revealed the presence of $\mathrm{CuSO}_{4} \cdot \mathrm{H}_{2} \mathrm{O}$ in live and dead biomass. EDAX confirmed the occurrence of sulphur, oxygen and $\mathrm{Cu}(\mathrm{II})$ in the cell wall.
\end{abstract}

Keywords: Aspergillus awamor;, Cu(II), Stress, Antioxidant enzymes, Biosorption.

Several inorganic and organic compounds such as heavy metals, fuels and petroleum industry products cause soil and water contamination. For this reason, research focused toward better decontamination methods and the development of new technologies is imperative (Velásquez \& Dussan, 2009).

Remediation methods for heavy metals differ from those for organic compounds. As compared to organic compounds, metals are non-biodegradable (Gupta \& Rastogi, 2008). Therefore, biomobilization is a valid concept in the management of metal pollution. Some metal ions, like $\mathrm{Cu}$ (II) and $\mathrm{Zn}$ (II) are essential for biological processes, but other nonessential metals like $\mathrm{Cd}(\mathrm{II})$ and $\mathrm{Hg}$ (II) are considered highly toxic elements to nearly all organisms even at low

e-mail: tawfeek.manal1@ @mail.com, Tel: 00201117132152 
concentrations (Guelfi et al., 2003). However, $\mathrm{Cu}$ (II) is toxic to most organisms at elevated concentrations, largely through enzyme inhibition and oxidation of membrane components as a result of the ability of $\mathrm{Cu}(\mathrm{II})$ to generate toxic hydroxyl radicals (Melo et al., 2004). Membrane damage then leads to rapid leakage of ions and other low molecular weight compounds (Soares et al., 2003).

Various techniques such as precipitation, coagulation, ion exchange, reverse osmosis, evaporation, filtration, electrochemical treatment and oxidation and reduction have been employed to remove toxic heavy metals from industrial wastewaters. Most of these techniques are ineffective or extremely expensive in terms of energy and reagent consumption, especially when concentrations of dissolved metals are on the order of $1-100 \mathrm{mg} / \mathrm{l}$ (Tang et al., 2008). Of these techniques, biosorption using the biomass of live or dead microorganisms has been proven effective as a consequence of high surface-to-volume ratio and selective adsorption of heavy metal ions. Additionally they can be used over a broad range of environmental conditions, reactions are fast and reversible are eco-friendly, economic and give excellent performance (Kapoor et al., 1999; Issac et al., 2012 and Huang et al., 2013). Bioaccumulation and biosorption are two processes, one based on the assimilation of metals inside the biomass and another process is biosorption, in which metallic ions remain at the cell surface (Vijayaraghavan \& Yun, 2008). Fungi have a high percentage of cell wall material that shows excellent metal-binding properties and exhibits marked tolerance towards metals and other factors such as low pH (Zafar et al., 2007). Recently, heavy metal accumulating strains have found a new role as small factories for the production of nanoparticles (Klaus-Joerger et al., 2001). In the concept of biosorption, several chemical processes may be involved, such as adsorption, ion exchange and covalent bonding with the biosorption sites of the microorganisms including carboxyl, hydroxyl, sulfhydryl, amino and phosphate groups (Montazer-Rahmati et al., 2011). The status of biomass (live or dead), types of biomaterials, properties of metal solution chemistry, ambient/ environmental conditions such as $\mathrm{pH}$, will all influence the mechanism of metal biosorption. The mechanisms of metal biosorption can be described according to the location where the metal is removed from the solution extracellular accumulation/ precipitation, cell surface sorption/ precipitation or intracellular accumulation (Veglio \& Beolchini, 1997).

Fungi such as Rhizopus arrhizus (Bahadir et al., 2007), A. niger (Tsekova et al. 2010 and Kumar et al., 2012), A. awamori (Gochev et al., 2010 and Velkova et al., 2012) have been used to remove different heavy metals.

The purpose of this study was to investigate the response and tolerance mechanism of $A$. awamori to $\mathrm{Cu}(\mathrm{II})$ stress. This study was undertaken also to determine the $\mathrm{Cu}$ (II) biosorption potential of live (not growing) and dead $A$. awamori biomass under different conditions.. The biosorption mechanism was also investigated by using FTIR, XRD and EDAX.

Egypt. J. Microbiol. 48(2013) 


\section{Material and Methods}

Microorganism, growth conditions and preparation of biosorbent

Aspergillus awamori ZU JQ 695830.1 was obtained from our laboratory stock cultures (Mycology Lab., Botany Department, Faculty of Science, Zagazig University). The isolate was cultured on potato/ glucose agar slants (PDA) (Gams et al., 1998) and stored at $4^{\circ} \mathrm{C}$.

For the preparation of the biosorbent, A. awamori was cultured on potato/ glucose broth (PD). After 5 days of incubation at $3^{\circ} \mathrm{C}$ on a rotary shaker at $125 \mathrm{rpm}$, the fungal growth was harvested, filtered and washed with distilled water to remove residual growth medium. The biomass was divided into two parts; the first one was used as live (not growing) biosorbent while the other part was dried to a constant weight at $6^{\circ} \mathrm{C}$ and powdered to be used as a dead biomass in the biosorption experiments.

\section{Metal solutions}

Stock metal solutions of $\mathrm{Cu}(\mathrm{II})$ were prepared by dissolving appropriate quantities of $\mathrm{CuSO}_{4} \cdot 4 \mathrm{H}_{2} \mathrm{O}$ salt in double distilled water. The stock solutions were diluted further with deionized distilled water to obtain working solutions of different concentrations.

Determination of minimum inhibitory concentration (MIC)

A sterilized solution of $\mathrm{CuSO}_{4} \cdot 4 \mathrm{H}_{2} \mathrm{O}$ was aseptically added to the sterilized PDA medium to final concentrations ranging from 0 to $3200 \mathrm{~g} / \mathrm{ml}$. The plates were centrally inoculated with $5 \mathrm{~mm}$ fungal plugs from 4 days old fungal colonies in three replicates and were incubated at $3^{\circ} \mathrm{C}$ for 7 days. MIC was identified as the minimum concentration of $\mathrm{Cu}(\mathrm{II})$ that inhibited visible growth of $A$. awamori.

\section{Effect of $\mathrm{Cu}(\mathrm{II})$ stress on A. awamori growth}

To investigate the response of $A$. awamori to heavy metal stress, the changes in radial growth, biomass production, protein content, peroxidase (POD), polyphenol oxidase (PPO), glutathione reductase (GR), total antioxidant and total thiol were determined.

To study the effect of $\mathrm{Cu}(\mathrm{II})$ on radial growth, the metal ion treated plates were inoculated as mentioned before for the determination of MIC. The diameters of the fungal colonies were measured in millimeters $(\mathrm{mm})$ at certain intervals.

To study the effect of metal ions on the biomass production of A. awamori, the fungus was grown in $250 \mathrm{ml}$ Erlenmeyer flasks containing $50 \mathrm{ml}$ of PD. Sterilized solutions of $\mathrm{Cu}$ (II) sulphate were aseptically added to the sterilized PDA medium to get final concentration ranging from $0-1000 \mu \mathrm{g} / \mathrm{ml}$, then incubated at $30^{\circ} \mathrm{C}$ for 6 days on a rotary shaker at $125 \mathrm{rpm}$. The biomass was harvested and dried to a constant weight at $60^{\circ} \mathrm{C}$. 
Scanning electron microscopy analysis (SEM)

Aspergillus awamori cells were fixed in $2.5 \%$ glutaraldehyde at $4^{\circ} \mathrm{C}$, for $24 \mathrm{~h}$ and then post-fixed in $1.0 \%$ osmium tetraoxide at room temperature for $1 \mathrm{~h}$ (Harely \& Ferguson, 1990). The samples were then dehydrated in acetone and coated with gold. The scanning and photographing were done using a Jeol scanning electron microscope (JEM-1200XII) (Regional Center of Mycology and Biotechnology, Cairo, Egypt).

Energy dispersive $X$ - ray microanalysis (EDAX)

Metal- loaded live and dead biomass samples were used for energy dispersive $\mathrm{X}$ - ray microanalysis using X- ray microanalyzer ( model Oxford 6587 INCA Xsight ) connected with a JEOL JSM- 5500 LV scanning electron microscope (Regional Center of Mycology and Biotechnology, Cairo, Egypt).

Transmission electron microscopy analysis (TEM)

A. awamori cells were fixed in $2.5 \%$ glutaraldehyde for $3 \mathrm{~h}$ (Gupta \& Berridge, 1966), washed twice with $0.2 \mathrm{M}$ phosphate buffer of $\mathrm{pH} 7.4$ for $30 \mathrm{~min}$, then post-fixed in $1.0 \%$ osmium tetraoxide for $2 \mathrm{~h}$ (Palade, 1952). After that, the cells were washed with phosphate buffer for $30 \mathrm{~min}$. All the previous steps of fixation were carried out at $4^{\circ} \mathrm{C}$. Samples were dehydrated in a graded ethanol series (50\%-100\%). They were then passed through three changes of acetone: ethanol (1:2, 1:1 and 2:0) for 10 min each and embedded in epoxy medium (Epon 812) (Luft, 1961). Blocks were sectioned with a diamond knife (ultramicrotome RMC USA) into ultrathin section about $70 \mathrm{~nm}$. These ultrathin sections were constructed with uranyl acetate (Sptempack \& Ward, 1969) followed by lead citrate (Reynolds, 1963) each for 30min. Transmission and photographing were done using a JEOL- 1010 electron microscope (Regional Center of Mycology and Biotechnology, Cairo, Egypt).

The response of $A$. awamori to $\mathrm{Cu}(\mathrm{II})$ stress

The effects of $\mathrm{Cu}(\mathrm{II})$ on the concentrations of total soluble protein, thiol content and total antioxidant and on the activities of peroxidase, glutathione reductase and polyphenol oxidase were determined. The fungal mycelia were ground using a cold mortar in an ice bath with $50 \mathrm{mM}$ cold phosphate buffer $(\mathrm{pH}$ 7.0) of 50mM EDTA. The cell suspensions were centrifuged at $6000 \mathrm{rpm}$ for $12 \mathrm{~min}$ at $4^{\circ} \mathrm{C}$. The supernatants and filtrates were used to elucidate the tolerance mechanism of A. awamori to $\mathrm{Cu}(\mathrm{II})$.

\section{Polyphenol oxidase}

Polyphenol oxidase (PPO) activity was determined according to Bergmeyer et al. (1974) with slight modifications. Briefly, the reaction mixture contained $200 \mu$ l of enzyme preparation in $0.1 \mathrm{M}$ potassium phosphate buffer $(\mathrm{pH} 7.0)$, $0.2 \mathrm{mM}$ guaiacol, $5 \mathrm{U} / \mathrm{ml}$ horseradish peroxidase and $10 \mathrm{mM}$ catechol as substrate, in a total volume of $1 \mathrm{ml}$. The reaction was incubated for $60 \mathrm{~min}$ at $30^{\circ} \mathrm{C}$. After the reaction was frozen for $10 \mathrm{~min}$, the developed color was measured at $436 \mathrm{~nm}$. One unit of the enzyme was expressed by the amount of enzyme that released $1 \mu \mathrm{mol} \mathrm{H}_{2} \mathrm{O}_{2}$ per min under optimal assay conditions.

Egypt. J. Microbiol. 48(2013) 


\section{Glutathione reductase}

Glutathione reductase (GR) activity was determined spectrophotometrically according to the method of Barata et al. (2000). The reaction mixture contained $3 \mathrm{ml} 100 \mathrm{mM}$ potassium phosphate buffer ( $\mathrm{pH} 7.5$ ) containing $1 \mathrm{mM} 2$ nitrobenzoic acid, $1 \mathrm{mM}$ oxidized glutathione and $0.1 \mathrm{mM}$ NADPH. The reaction was started by the addition of $50 \mu l$ of mycelium extract. The changes in absorbance due to the reduction of oxidized glutathione were monitored at $412 \mathrm{~nm}$ for $2 \mathrm{~min}$.

\section{Total antioxidant}

Concentrations of total antioxidants of the crude fungal extract were determined by the ferric-thiocyanate method (Gupta et al., 2004) with slight modifications. In brief, $1 \mathrm{ml}$ of the crude enzyme preparation was mixed with $0.2 \mathrm{ml}$ of ferrous chloride $(20 \mathrm{mM})$ and $0.2 \mathrm{ml}$ ammonium thiocyanate $(30 \%)$. After incubation for $10 \mathrm{~min}$, the developed red color was measured at $500 \mathrm{~nm}$.

\section{Protein measurement}

The method of Lowery et al. (1951) was used to measure extracellular and intracellular protein.

\section{Assay of total thiol content}

For total thiol assay, a modified Ellman (1959) method was followed. Three milliliters of samples was mixed with $2 \mathrm{ml}$ of phosphate buffer $(\mathrm{pH} 7.0)$ and $5.0 \mathrm{ml}$ distilled water and they were mixed well to get a $10 \mathrm{ml}$ reaction mixture. Twenty micro liters of $0.01 \mathrm{M}$ DTNB solution was added to $3 \mathrm{ml}$ of the reaction mixture, shaken well and absorbance was recorded at $412 \mathrm{~nm}$.

\section{High performance liquid chromatography (HPLC)}

To investigate the role of oxalic acid in the tolerance mechanism, analysis of oxalic acid in control and $\mathrm{Cu}$ (II)-stressed samples was carried out using HPLC system comprising of GBC UV/vis detector, GBC LC 1110 pump controlled by WinChrome chromatography ver 1.3 software. The eluent was $85 \%$ acetonitrile: $15 \%$ water and the column used was a Kromasil $100 * 4.6 \mathrm{~mm}$ with flow rate $1 \mathrm{ml} / \mathrm{min}$. The detection was at $254 \mathrm{~nm}$ (Regional Center of Mycology and Biotechnology, Cairo, Egypt).

\section{Batch biosorption studies}

To investigate the relationship between tolerance and biosorption potential of $A$. awamori to $\mathrm{Cu}(\mathrm{II})$, batch biosorption experiments were carried out. In addition, a comparison between live (not growing) and dead biomass was studied.

All uptake experiments were performed by suspending the biosorbent in $100 \mathrm{ml}$ of solution at the desired $\mathrm{pH}$, biosorbent dose, initial metal ion concentration and contact time. Sorption contact experiments with metal bearing solutions were run in triplicate. 


\section{Effect of initial $\mathrm{pH}$}

To evaluate the effect of initial $\mathrm{pH}$ on metal uptake, the $\mathrm{pH}$ of the solution was adjusted in the range between 2 to 6 viz. 2, 3, 4, 5 and 6 before mixing with biomass. The $\mathrm{pH}$ was adjusted to the required value with aqueous solution of $0.1 \mathrm{~N} \mathrm{HCl}$ or $0.1 \mathrm{~N} \mathrm{NaOH}$. Initial $\mathrm{Cu}(\mathrm{II})$ concentration was $500 \mathrm{mg} / \mathrm{l}$, biosorbent dose was $1 \mathrm{~g} / \mathrm{l}$ at $28^{\circ} \mathrm{C}$ and contact time was $30 \mathrm{~min}$ (dead biomass) and $180 \mathrm{~min}$ (live biomass). The concentration of unadsorbed $\mathrm{Cu}$ (II) in the supernatants was measured by atomic adsorption spectrophotometer (Model unicam 969, Centric Laboratory, Faculty of Agriculture, Zagazig University).

\section{Effect of initial metal ion concentration}

The batches were set at different initial metal ion concentration of $\mathrm{Cu}$ (II). Aliquots $(50 \mathrm{ml})$, of $150,200,300,500$ and $700 \mathrm{mg} / \mathrm{l}$ concentrations of $\mathrm{Cu}$ (II) were added to $1 \mathrm{~g} / \mathrm{l}$ biomass at $28^{\circ} \mathrm{C}$ in $500 \mathrm{ml}$ Erlenmeyer flasks.

\section{Effect of biosorbent dose}

Live and dead biomass of $A$. awamori with concentrations $1,2,3$ and $5 \mathrm{~g} / 1$ (with respect to cell dry weight) were added to $50 \mathrm{ml}$ of $500 \mathrm{mg} / \mathrm{l} \mathrm{of} \mathrm{Cu}$ (II) and shaken on a rotary shaker incubator at $28^{\circ} \mathrm{C}$ and $125 \mathrm{rpm}$.

\section{Effect of contact time}

The biomass concentration $(1 \mathrm{~g} / \mathrm{l})$ was exposed with $500 \mathrm{mg} / \mathrm{l} \mathrm{Cu}(\mathrm{II})$ solutions for different periods of time. Samples were analyzed at intervals of 0, 0.17, 0.50, $1.00,1.30,2.00,3.00,4.00,5.00,8.00,16.00$ and $24 \mathrm{~h}$ and the adsorption profile was monitored. For all graphical representations, the mean values of three replicates of the batch experiments were plotted.

\section{Biosorption data evaluation}

The amount of metallic ions biosorbed per gram of biomass (q) was determined using the following equation:

$$
\text { Biosorption capacity }(\mathrm{q})=\frac{C_{i}-C_{f}}{M} \mathrm{~V}
$$

where, $C_{i}$ is the initial metal ion concentration $(\mathrm{mg} / \mathrm{l}), \mathrm{C}_{\mathrm{f}}$ is the final metal ion concentration $(\mathrm{mg} / \mathrm{l}), \mathrm{M}$ is the mass of the biosorbent $(\mathrm{g}), \mathrm{V}$ is the volume of the metal solution and $\mathrm{q}$ is the biosorption capacity $(\mathrm{mg} / \mathrm{g})$.

\section{Fourier transform infrared spectroscopy (FTIR)}

Infrared spectra of native cells as well as live and dead treated ones were recorded over the region 400-4000 $\mathrm{cm}^{-1}$ with Perkin- Elmer FTIR 1650 spectrophotometer. The samples were examined in $\mathrm{KBr}$ containing $3 \%$ (W/W) of finely ground powder of each sample ( Center of Microanalysis, Cairo University, Cairo, Egypt).

$X$-ray powder diffraction analysis (XRD)

$\mathrm{X}$ - ray diffraction patterns of powdered samples of metal-free and metalloaded live and dead biomass were recorded in a Broker D8 Advanced target $\mathrm{Cu}$ 
Ko $\alpha$ powder diffractometer $\left(\lambda=1.5418 \mathrm{~A}^{\circ}\right.$ ) over the range of $0-60(2 \theta)$ ( Central Metallurgical \& Development Institute, Helwan, Egypt).

\section{Results and Discussion}

\section{Heavy metal tolerance}

Metal toxicity can be indicateed by MIC. Numerous methods have been employed to determine metal tolerance in fungi. In vitro assays include sensitivity to spore germination, mycelia growth extension and biomass production in the presence of various concentrations of metal salts in broth and/ or agar nutrient medium (Ahmad et al., 2011). Results showed very high fungal tolerance to $\mathrm{Cu}$ (II) concentration up to $3100 \mathrm{mg} / \mathrm{l}$ which is more than 30000 fold the maximum admissible $\mathrm{Cu}(\mathrm{II})$ concentration in drinking water $(0.1 \mathrm{mg} / \mathrm{l})(\mathrm{WHO}$, 2008). MIC has been reported to be species specific and metal dependant (Ahmad et al., 2006). The MIC values of A. awamori in this study are very much higher than those reported by Akhtar et al. (2013) for related fungus. They reported that $\mathrm{MIC}$ of $\mathrm{Cu}(\mathrm{II})$ of $A$. niger (GF-1), (GF-5) and (SF-5) were 318, 63.5 and $445 \mathrm{mg} / \mathrm{l}$, respectively. There are only three known mechanisms for heavy metal resistance (Nies, 1999). First, the accumulation of the respective ion can be diminished by efflux. Second, cations, especially the sulfer lovers (e.g. $\mathrm{Cd}(\mathrm{II})$ ) can be segregated into complex compounds by thiol-containing molecules. Third, some metal ions may be reduced to a less toxic oxidation state.

\section{Effect of $\mathrm{Cu}(\mathrm{II})$ on the growth of A. awamori}

Figures $1 \mathrm{a}$ and $\mathrm{b}$ display the influence of $\mathrm{Cu}$ (II) on the fungal growth that was assessed in the terms of colony diameter and mycelia production over 6 days incubation. Aspergillus awamori was resistant to high concentrations of $\mathrm{Cu}(\mathrm{II})$. An increase in the length of the lag phase was evident only in $\mathrm{Cu}$ (II) concentrations starting from $1200 \mathrm{mg} / \mathrm{l}$ (Fig. 1a). A complete inhibition in the radial growth and biomass production was observed at $3100 \mathrm{mg} / \mathrm{l}$ and $800 \mathrm{mg} / \mathrm{l}$ concentrations of $\mathrm{Cu}(\mathrm{II})$, respectively. Growth reduction is a typical response of fungi to the toxicity of heavy metals (Baldrian, 2003). In liquid medium, the metal toxicity becomes more evident when the medium is supplemented with lower concentrations than agar plates. This apparent abnormality is due to the more intimate contact between the cells and the ions and also due to the absence of the protective chelating effect of the agar (Ruta et al., 2010). In liquid media, the pellets at $600 \mathrm{mg} / \mathrm{l}$ were larger and more yellowish in color than those of the control which were smaller and white. Filamentous fungi exhibit two extreme types of morphology in submerged culture, pelleted and filamentous forms ( $\mathrm{Li}$ et al., 2009). It was reported that when fungal cells suffer high oxygen concentration, they generally adopt morphological forms which reduce the surface area exposed to the environment, such as adhesion of mycelia, formation of small and smooth pellets, and increased pellet density so the inside cells are relatively resistant to the high level of oxygen minimizing ROS mediated damage (Bai et al., 2004). 


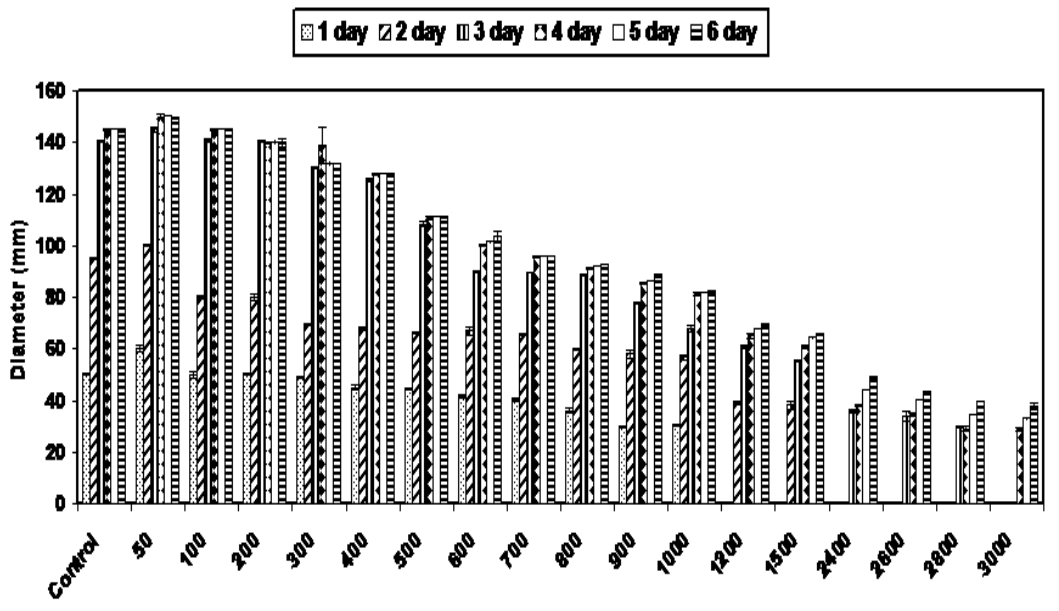

$\mathrm{Cu}$ (II) concentration

Fig. 1a. Effect of $\mathrm{Cu}(\mathrm{II})$ supplementation on the radial growth of A. awamori. Data represent the mean of 3 measurements

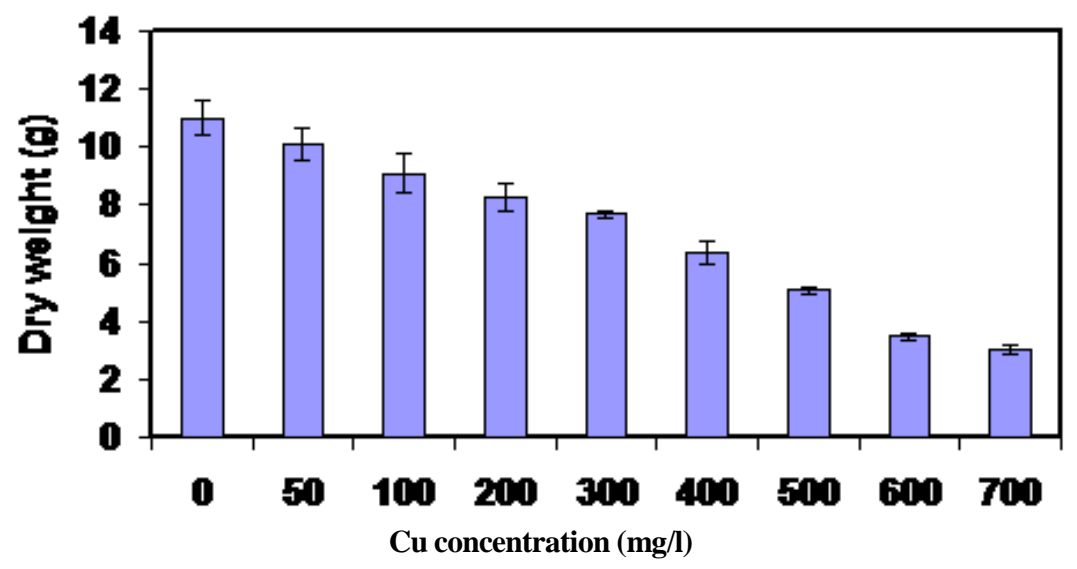

Fig. 1b. Effect of different concentrations of $\mathrm{Cu}(\mathrm{II})$ on mycelium dry weight of $A$. awamori. Data represent means of 3 measurements \pm SE.

Assessment of A. awamori morphological changes in response to $\mathrm{Cu}$ (II) stress and the quantification of these metal ions within the fungus was performed by SEM investigation and EDAX microanalysis. Control biomass had heavily conidiated vesicles with smooth conidiophore (Fig. 2a) and normal conidia (Fig. $2 \mathrm{~b}$ ). Under $\mathrm{Cu}(\mathrm{II})$ stress, some granules appeared on the conidiophores. There were no sterigmata at the base of the vesicle. At the middle and the upper portion of the vesicle sterigmata appeared but without conidia (Fig. 2c). The inhibition of conidial formation may be due to the failure in either the division of sterigmata Egypt. J. Microbiol. 48(2013) 
nuclei or in the development of conidial initials. Some abnormal conidia were observed (Fig. 2d). Toxic heavy metals can inhibit growth, cause morphological changes and affect the reproduction of organisms. The reproductive stage of spore formation and conidia production are much more sensitive to heavy metals than mycelial growth in saprophytic and mycorrhizal soil fungi (Ali, 2007).
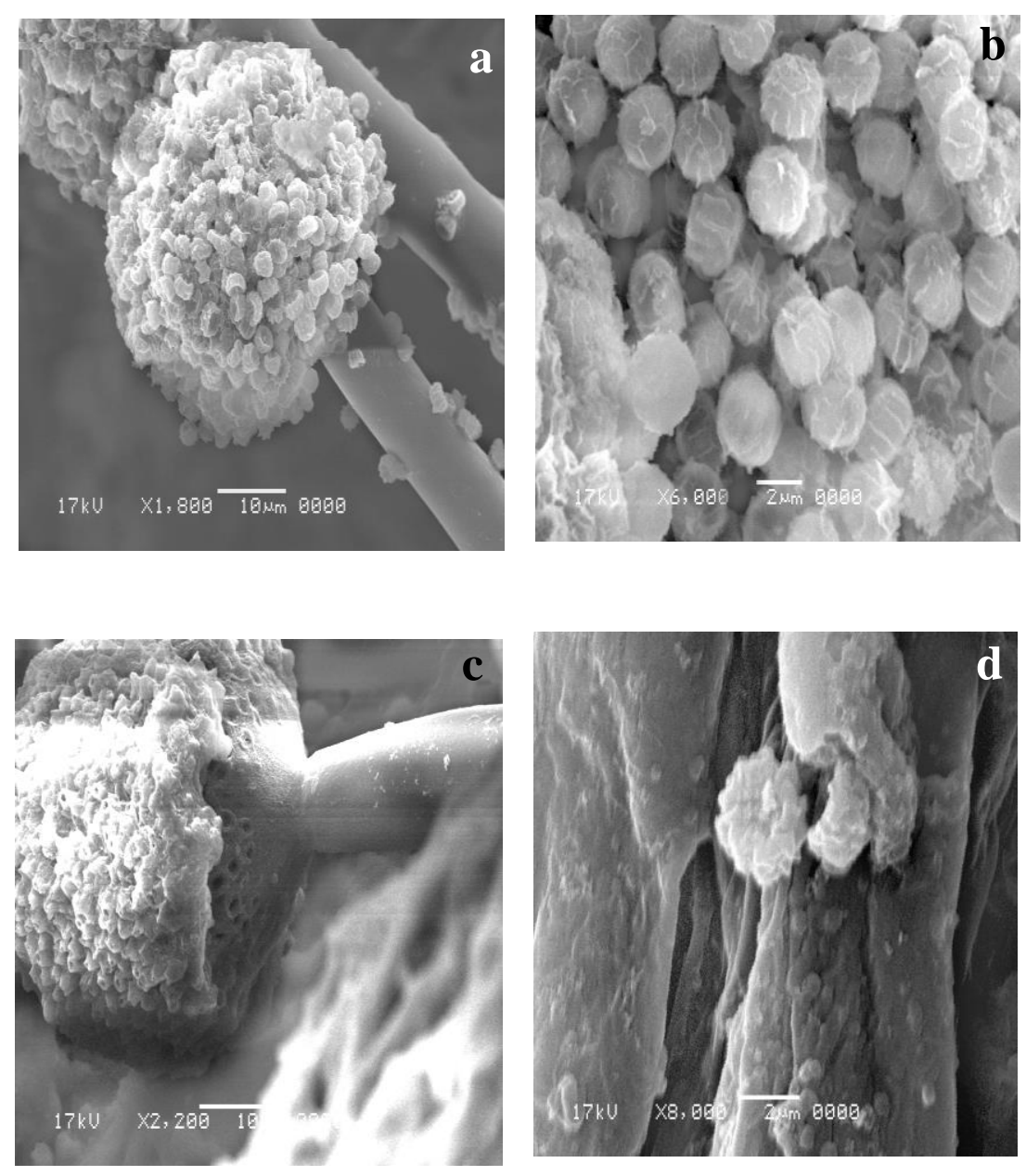

Fig. 2. SEM A. awamori (a and b) native cells, (c and d) $\mathrm{Cu}$ (II)-stressed cells .

EDAX microanalysis revealed that $\mathrm{Cu}(\mathrm{II})$ ions were bound to the fungal mycelia (Fig. 3). Quantification of $\mathrm{Cu}$ (II) ions gave confirmation of their accumulation by $A$. awamori. 


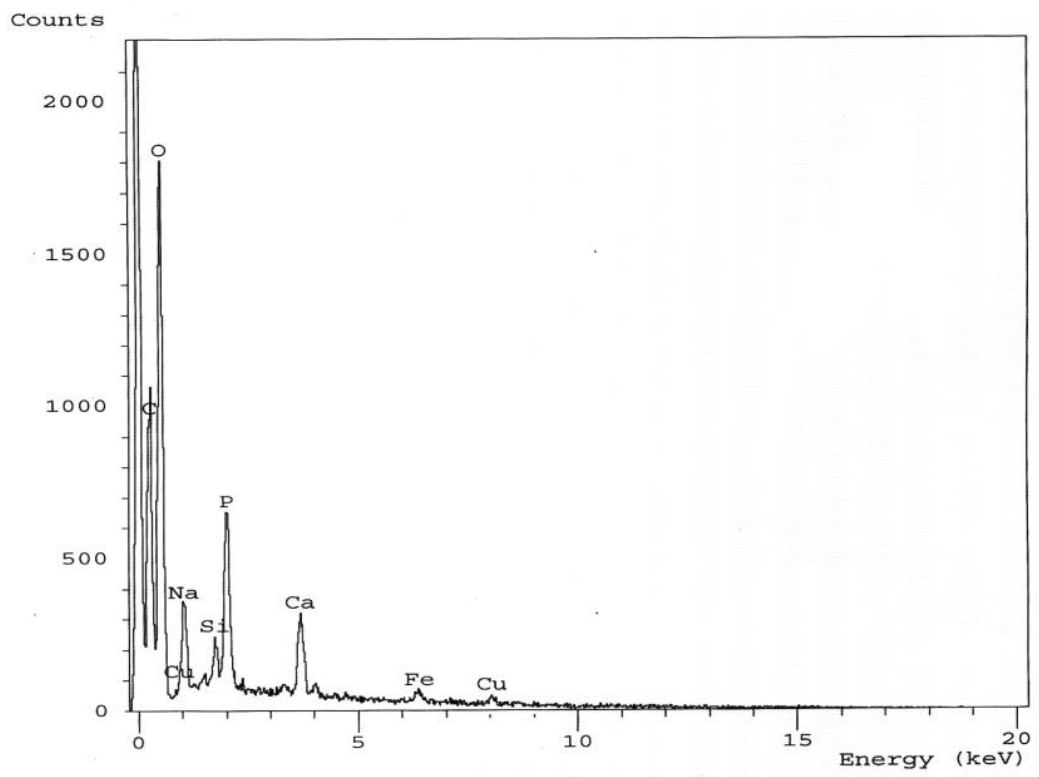

Fig. 3. EDAX of A. awamori $\mathrm{Cu}(\mathrm{II})$ - loaded cells.

Aspergillus awamori biomass samples before and after $\mathrm{Cu}(\mathrm{II})$ exposure were subjected to TEM investigation to ascertain the cellular localization of accumulated metals (Fig. 4a-d). Ultra thin sections of metal-less cells revealed a distinct cell wall 400nm in thickness, clear cytoplasm with normal mitochondria and few electron dense areas probably representing the genetic material and cytoplasmic deposits (Fig. 4a). Septum thickness was found to be $220 \mathrm{~nm}$ (Fig. 4b). From TEM micrographs of $\mathrm{Cu}$ (II)-loaded cells, it can be seen that cell walls of some cells became much thicker $(710 \mathrm{~nm})$. Also, the cell wall seemed to be closely related with $\mathrm{Cu}$ (II) enrichment as $\mathrm{Cu}$ (II) particles are dotted within its layers and on the inner surface (Fig. 4c and d). Previous studies have indicateed that the fungal cell wall binds to approximately $50 \%$ of the metal ions (Joner et al., 2000), most of which bind to negatively charged components of the cell wall, such as chitin and melanin (Ferrol et al., 2009). Decreasing the bioavailability of the toxic metals/ metalloids can be managed through extracellular complexation, precipitation and binding to cell wall constituents (Pòesi, 2011). Vieira \&Volesky (2000) reported that uranium sequestered in the layers of the cell wall material of Rhizopus arrhizus while thorium sequestered on the surface of the cell wall of the same fungus. Also, septa relatively doubled their thickness (500nm) (Fig. 4d) thanks to the deposition of amorphous masses that became evident in the transeverse wall. Plasmolysis and undulation of the plasma membrane were very evident. This was due to the toxicity of high concentration of $\mathrm{Cu}(\mathrm{II})$. This retraction may suggest the loss of plasma membrane turgidity and may be related to the exocyosis to the periplasmic space (Osumi, 1998). Electron dense deposits

Egypt. J. Microbiol. 48(2013) 
were observed in the periplasm. Apart from cell wall biosorption, intracellular accumulation of $\mathrm{Cu}$ (II) occurred as well. Electron dense vacuoles were very apparent. Transporter proteins involved in metal tolerance facilitate the efflux of toxic metal ions from the cytosol or they allow metal sequestration into intracellular compartments, for example, vacuoles (Hall, 2002). Vacuolation and compartmention are essential for metal detoxification (Gonzalez et al., 2008). Some fungi can precipitate metals in amorphous and crystalline forms, such as oxalates and other secondary mycogenic minerals (Burford et al., 2006). Copper (II) tolerance by fungi has been extensively investigated, and the ability to prevent cellular entry or reducing accumulation of $\mathrm{Cu}$ (II) has been reported as the main mechanism for tolerance (Gadd \& White, 1989).
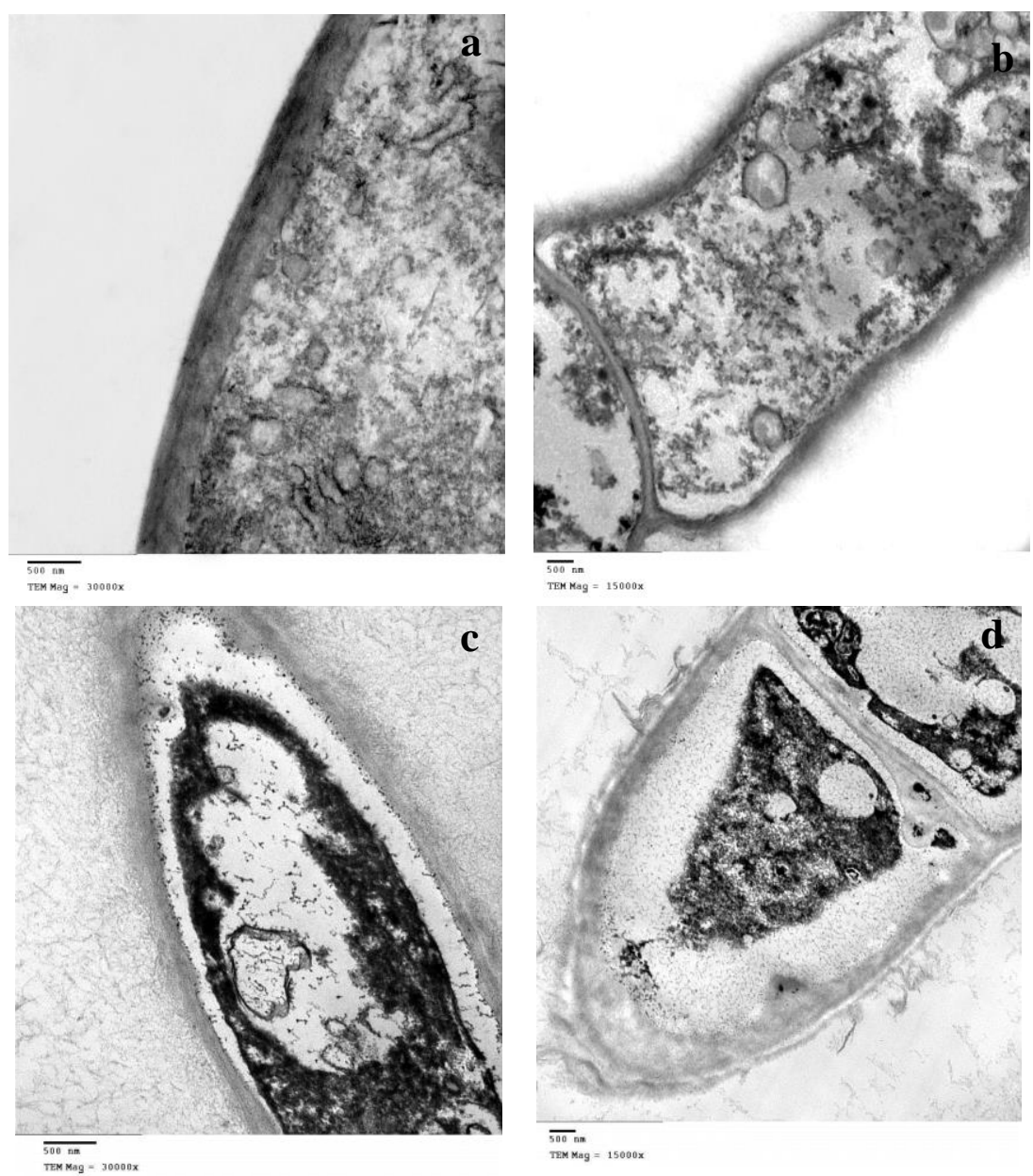

Fig. 4. TEM A. awamori (a and b) native cells, (c and d) $\mathrm{Cu}(\mathrm{II})-$ stressed cells. 
Effect of $\mathrm{Cu}(\mathrm{II})$ on Peroxidase (POD), polyphenol oxidase (PPO) and glutathione reductase (GR) activities of A. awamori

The activities of POD, PPO and GR were measured to elucidate their role in coping with oxidative stress induced by $\mathrm{Cu}$ (II) exposure. Following the treatment with 50 and $100 \mathrm{mg} / \mathrm{l}$ concentrations of $\mathrm{Cu}(\mathrm{II})$, complete inhibition in POD and PPO activities was observed (Fig. 5). Hossain \& Kermasha (1998) reported that copper-metallothionein (Cu-MT) by donating copper, could act as an inhibitor for PPO activity in A. niger. Peroxidase and PPO activities increased with further increase in $\mathrm{Cu}(\mathrm{II})$ concentration stress and were found to be maximum at $300 \mathrm{mg} / \mathrm{l}$ concentration of $\mathrm{Cu}$ (II) then reduced. An increase in POD and PPO activities indicateed that there was an effort on part of the fungus to minimize or neutralize the hazardous effect of ROS generated by $\mathrm{Cu}(\mathrm{II})$ treatment and that accumulation in the mycelium is required to induce the observed changes. The gradual decrease of enzyme activity suggests that the generated ROS caused irreversible oxidative damage in the fungal cell and inhibited POD activity (Guelfi et al., 2003).

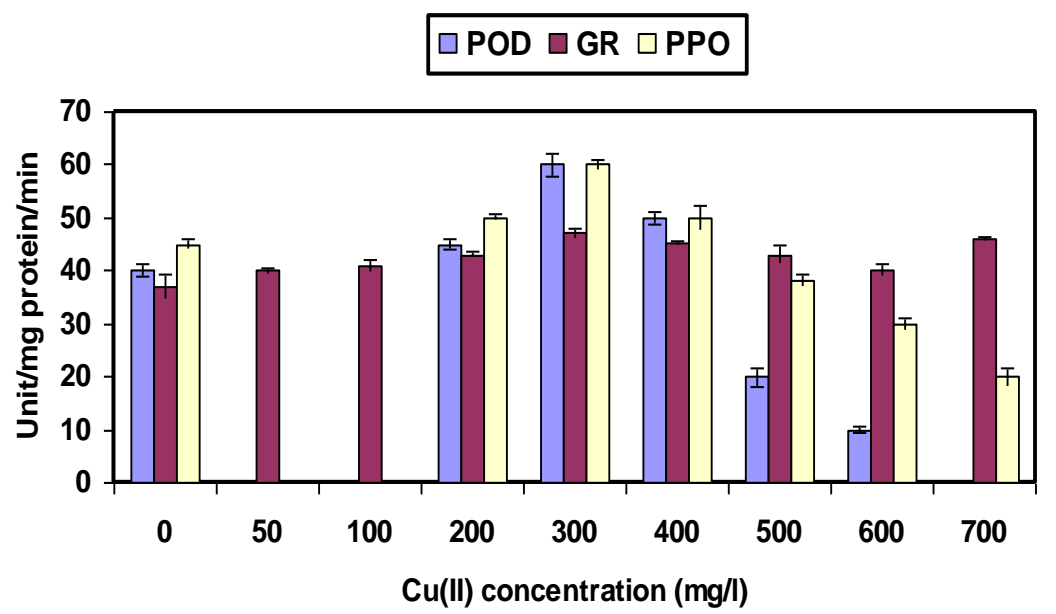

Fig. 5. Peroxidase (POD), polyphenol oxidase (PPO) and glutathiductase (GR) activity in $A$. awamori under different $\mathrm{Cu}$ (II) concentrations stress.

Glutathione, a tripeptide (-t-glutamyl-t- cystinylglycine), is one of the major antioxidant molecules of the cell, and is thought to play a vital role in buffering the cell against ROS (Stephen \& Jamieson, 1996). Glutathione reductase (GR) also can remove $\mathrm{H}_{2} \mathrm{O}_{2}$ and maintains a balance between reduced glutathione (GSH) and oxidized glutathione (GSSG), as the latter is toxic to cells (Guelfi et al., 2003). Activity of GR in A. awamori gradually increased by treatment with low concentrations of $\mathrm{Cu}$ (II) (Fig. 5). When the concentration of $\mathrm{Cu}$ (II) increased to $300 \mathrm{mg} / \mathrm{l}$, GR activity reached its maximum value of $47 \mathrm{U} / \mathrm{mg}$ protein. Beyond this concentration, progressive decrease occurred. An increase in GR activity probably occurred to minimize the toxic effect of $\mathrm{H}_{2} \mathrm{O}_{2}$ and other ROS generated

Egypt. J. Microbiol. 48(2013) 
due to $\mathrm{Cu}$ (II) toxicity. Comparable results were also obtained (Guelfi et al., 2003; Ban et al., 2012 and Chakraborty et al., 2012).

Effect of $C u(I I)$ on total antioxidant of A. awamori

Antioxidants (both enzymatic and nonenzymatic) provide protection against deleterious metal-mediated free radical attacks (Volka et al., 2013). Thus, the influence of $\mathrm{Cu}(\mathrm{II})$ on non enzymatic antioxidant production was determined. After $\mathrm{Cu}$ (II) stress, a complete inhibition in nonenzymatic antioxidants was observed. In the case of $\mathrm{Cu}(\mathrm{II})$ stress, $A$. awamori was more tolerant as indicateed before. The toxic effect of $\mathrm{Cu}(\mathrm{II})$ may be diminished by efflux (Nies, 1999) or by the previously mentioned ultra structural changes like an increment in cell wall thickness and vacoulation. However it is apparent that enzymatic antioxidants had a greater role than nonenzymatic in alleviating stress induced by $\mathrm{Cu}(\mathrm{II})$.

Effect of $\mathrm{Cu}(I I)$ on soluble protein content of A. awamori

Soluble protein exudation is assumed to be one of the mechanisms of heavy metal tolerance and varies depending on the species, the specific heavy metal and its concentration (Weishuang et al., 2009). Changes in the intracellular and extracellular soluble protein content in A. awamori under different concentrations of $\mathrm{Cu}$ (II) are shown in Fig.6. After $\mathrm{Cu}$ (II) treatment, extracellular protein content gradually increased while intracellular protein content decreased. The maximum values were observed at $400 \mathrm{mg} / \mathrm{l}$ concentration of $\mathrm{Cu}(\mathrm{II})$. A . awamori synthesized more protein up to certain level of $\mathrm{Cu}$ (II) treatment, a survival strategy which again may reflect the possibility of the Arndt-Schutrz effect. This results in the accumulation of toxins in non-lethal concentrations at the cell surface to cause alteration in the cellular permeability. This in turn leads to a more free flow of nutrients within cells and thus metabolic activity increases (Babich \& Stotzky, 1980 and Ahonen- Jounarth et al., 2004). Guelfi et al. (2003) suggested that the higher concentrations of Cd(II) induced the autolysis of the $A$. nidulans mycelium, with subsequent proteolytic breakdown and reduction in the protein content.

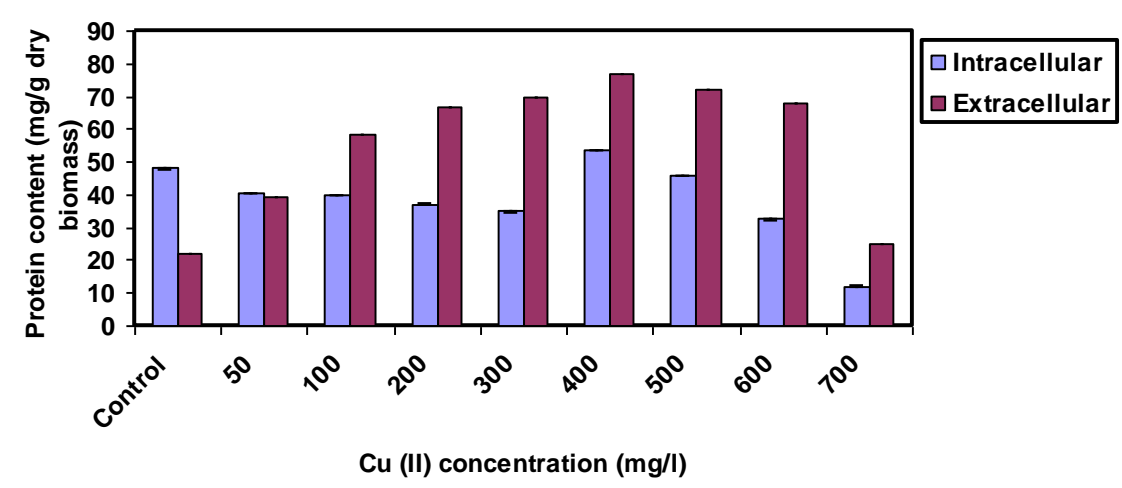

Fig. 6. Extracellular and intracellular protein content in A. awamori under different $\mathrm{Cu}(\mathrm{II})$ concentrations stress . 
Effect of $\mathrm{Cu}(\mathrm{II})$ on thiol content of A. awamori

Thiol compounds play an important role in ROS perception. Immediate oxidation of protein SH-groups in the presence of ROS, diversity of the products produced (thiyl radical - $\mathrm{S}^{-}$, disulfide -S-S-, sulfenic - $\mathrm{SOH}$, sulfinic $-\mathrm{SO}_{2} \mathrm{H}$ and completely oxidized sulfonic acid $-\mathrm{SO}_{3} \mathrm{H}$ as well as formation of sulfenylamide or sulfonamide with the adjacent amino acid residues) and reversibility of these reactions make thiols the key compounds in reception and transduction of the ROS signal (Poole et al., 2004). At 50mg/l concentration of $\mathrm{Cu}(\mathrm{II})$, there was an increase in extracellular thiol content (176.1\% with respect to control) (Fig. 7). With further increase in $\mathrm{Cu}$ (II) concentration, a decrease in extracellular (but still higher than that of control) and intracellular thiol content was observed. Then, at $500-700 \mathrm{mg} / \mathrm{l}$ concentrations of $\mathrm{Cu}(\mathrm{II})$, intracellular thiol content increased. An increase in thiol content indicateed the role of thiol in the tolerance or detoxification of $\mathrm{Cu}(\mathrm{II})$. The level of intracellular thiol content was found to be elevated during metal stress. Thiols are a well- known for metal chelation and detoxification. Some important members of the thiol family are capable of binding heavy metal ions to thiol- containing compounds such as GSH and sequestering these metal-thiol complexes into sub- cellular compartments of vacuoles (Schmoger et al., 2000 and Ge et al., 2011).

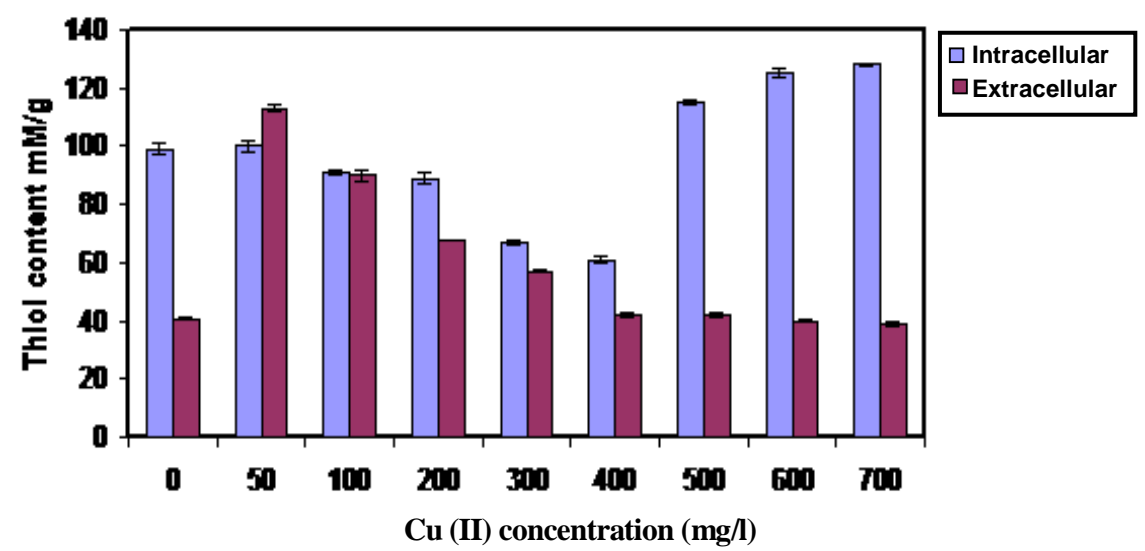

Fig. 7. Extracellular and intracellular thiol content in A. awamori under different $\mathrm{Cu}$ (II) concentration.

\section{Oxalic acid secretion}

Oxalate secretion is well-documented in both brown-rot, white-rot and A.niger and this process seems to be stimulated under $\mathrm{Cu}$ (II) stress (Clausen \& Green, 2003 and Jarosz-Wilkolazka et al., 2006). HPLC chromatograms of control and $\mathrm{Cu}(\mathrm{II})$-stressed samples (Fig. 8a and b, respectively) revealed that the concentration of oxalic acid was found to be 16.1 and $28.9 \mathrm{mg} / \mathrm{ml}$, respectively. These results indicate that $\mathrm{Cu}$ (II) stress stimulated the production of oxalic acid (79.5\%, with respect to control). The production of oxalate in most brown-rot copper-tolerant fungi increased 2- to 17-fold when grown in wood preservative containing copper rather than in untreated wood (Green \& Clausen, 2001). The

Egypt. J. Microbiol. 48(2013) 
detoxification strategies of A. foetidus occurred by two mechanisms. One of them is the production of extracellular metabolites (e.g. citrate, oxalate) that is capable of adsorbing and precipitating the metal ions on the cell surface (Ge et al., 2011).
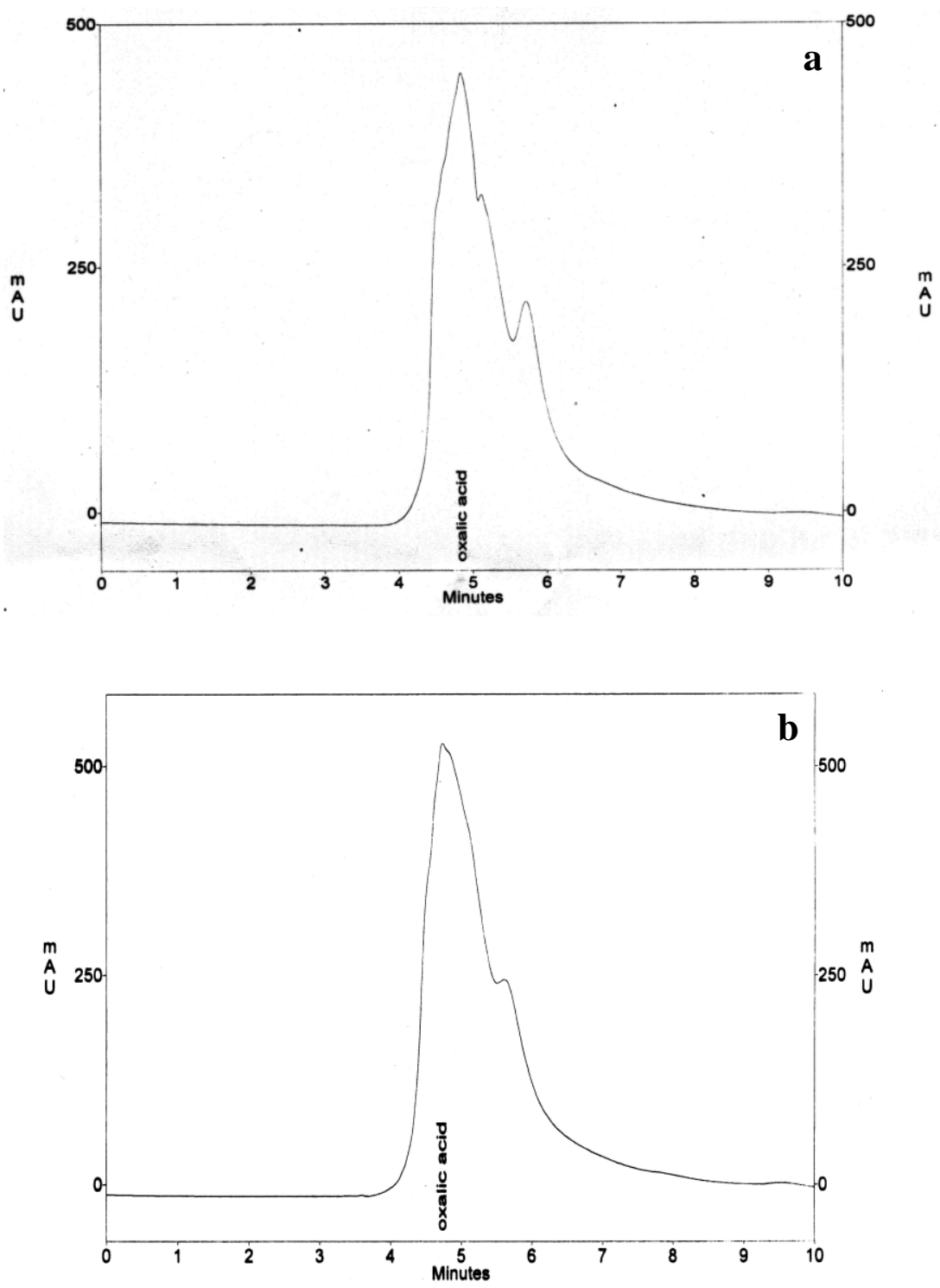

Fig. 8. HPLC chromatograms of A. awamori (a) native cells, (b) $\mathrm{Cu}(\mathrm{II})$ - stressed cells. 


\section{Biosorption results}

Initial metal ion concentration

As the metal ions concentration increased, biosorption capacity also increased and reached saturation values of 73 and $50 \mathrm{mg} \mathrm{Cu}$ (II) for live and dead biomass, respectively, at $500 \mathrm{mg} / \mathrm{l}$ concentration of metal ions (Fig. 9). The uptake capacity was reduced with the rise in initial metal ion concentration to $700 \mathrm{mg} / \mathrm{l}$. At lower initial solute concentration, the ratio of the initial moles solute to the available surface area was low; subsequently, the fractional sorption become independent of the initial concentration. When the surface active sites have been completely covered with metal ions, the adsorption has reached a limit which can be described by the maximum biosorption capacity. At higher concentrations, the sites available for sorption become fewer compared to the moles of solute present and, hence, the removal of solute was strongly dependent upon the initial solute concentrations (Binupriya et al., 2007).

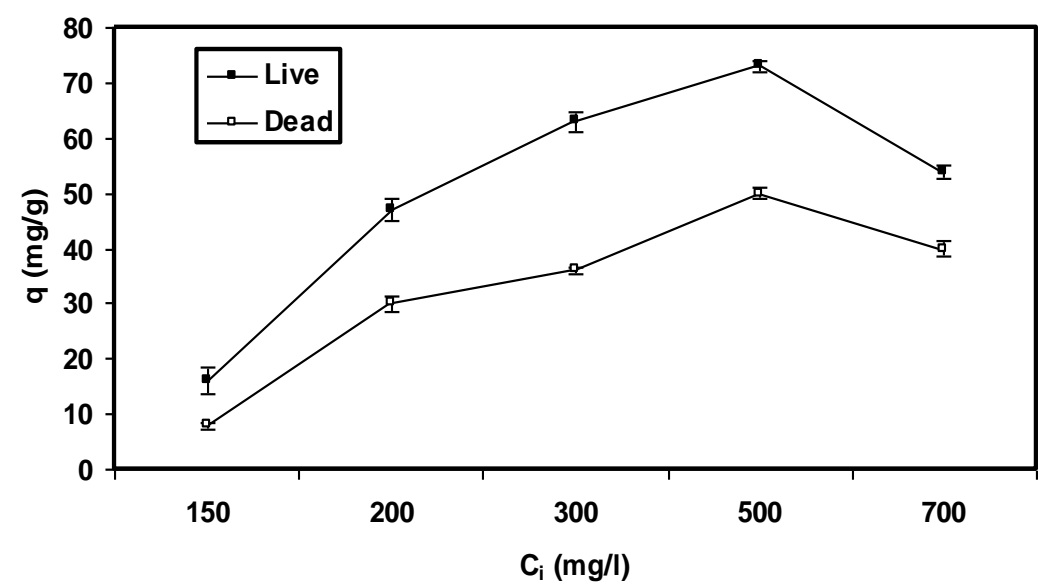

Fig. 9. Effect of initial metal ion concentration $\left(\mathrm{C}_{\mathrm{i}}\right)$ on $\mathrm{Cu}(\mathrm{II})$ uptake capacity of live and dead biomass of $A$. awamori. Biosorption conditions: $\mathrm{m}=1 \mathrm{~g} / \mathrm{l}$; $\mathrm{pH}=4.0$; $\mathrm{t}=30 \mathrm{~min}$ (for dead biomass) and $180 \mathrm{~min}$ (for live biomass).

Although A. awamori was tolerant for $\mathrm{Cu}(\mathrm{II})$, its biosorption capacity was not as high as expected. In this respect, Ruta et al. (2010) reported that the most of tolerant strains of yeast were hypo accumulators, owing to their gained tolerance to either reduced metal uptake or to enhanced export activity. Other explanation by Viraraghavan \& Srinivasan (2011) was that the biosorption was higher for metals with larger ionic radius, the exceptions being chromium and the alkali metal ions. Ionic radius of $\mathrm{Cu}(\mathrm{II})=128 \mathrm{pm}$.

\section{Initial $\mathrm{pH}$}

The effect of solution $\mathrm{pH}$ on the biosorption process can vary with the type of biomass and the type of metal ion being studied (Akar et al. 2007). Solution $\mathrm{pH}$ influences surface metal binding sites of the biosorbents and the chemistry of the cell wall as well as physicochemistry and hydrolysis of Egypt. J. Microbiol. 48(2013) 
metals (Tsekova et al., 2010). The effect of initial $\mathrm{pH}$ was evaluated in the range of 2-6 to avoid the precipitation of metal hydroxide. Yahya et al. (2009) and Xiao et al. (2010) stated that at solution pH of above 6.3, the $\mathrm{Cu}$ (II) ions precipitate and making the biosorption of $\mathrm{Cu}(\mathrm{II})$ impossible. As seen in Fig. 10, low pH (2.0) had more drastic effect on $\mathrm{Cu}(\mathrm{II})$ biosorption capacity of live cells $(5.0 \mathrm{mg} / \mathrm{g})$ than that of dead cells $(13.0 \mathrm{mg} / \mathrm{g})$. This is due to protein denaturation at low $\mathrm{pH}$ (Rothchild \& Mancinelli, 2001). It can be seen that $\mathrm{Cu}$ (II) biosorption capacity increased with increasing initial $\mathrm{pH}$ and began to decline after reaching maximum value at $\mathrm{pH} 4.0$ for dead and live biomass. A sudden increase in sorption with a slight increase in $\mathrm{pH}$ was observed and referred to as an adsorption edge (Varshney et al., 2011). The increase in biosorption capacity may be related to the ionization of functional groups which serve as the binding sites. In this study, the lower biosorption capacity at $\mathrm{pH}$ values below 4.0 may due to hydrogen ions that compete with metal ions on the biosoprtion sites. According to Rathinam et al. (2010), the enhancement of biosorption capacity in the range of $\mathrm{pH} 3.0-5.0$ was due to more negatively charged functional groups (carboxyl, amine or hydroxyl) being exposed. The decrease in biosorption above $\mathrm{pH} 4.0$ might be attributed to the speciation of the metal ions, such as the formation of $\mathrm{Cu}(\mathrm{OH})_{2}$ ions that do not adsorb well and resulted in the reduction of biosorption.

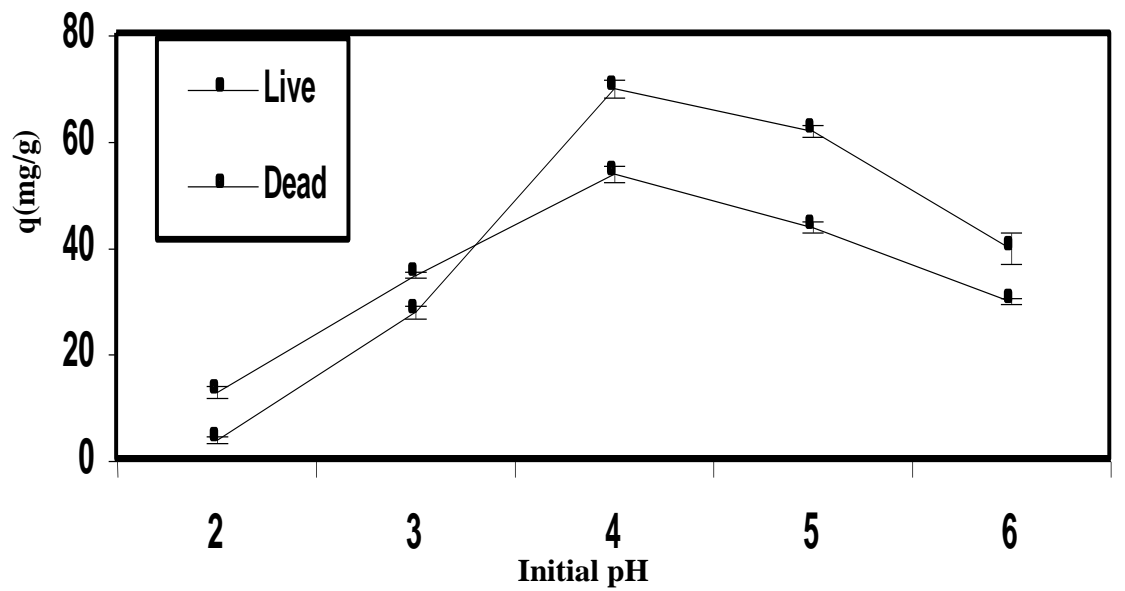

Fig. 10. Effect of initial pH on $\mathrm{Cu}(\mathrm{II})$ uptake capacity of live and dead biomass of $A$. awamori. Biosorption conditions: $C_{i}=500 \mathrm{mg} / \mathrm{l} ; \mathrm{m}=1 \mathrm{~g} / \mathrm{l} ; \mathrm{t}=30 \mathrm{~min}$ (for dead biomass) and 180min (for live biomass).

\section{Biosorbent concentration}

The biosorption of $\mathrm{Cu}(\mathrm{II})$ with different biosorbent concentrations is shown in Fig. 11. The uptake capacities of live and dead biomass for $\mathrm{Cu}(\mathrm{II})$ decreased with increasing biomass concentration. The highest uptake capacities of live and dead biomass for $\mathrm{Cu}(\mathrm{II})$ were observed at $1 \mathrm{~g} / \mathrm{l}$ concentration. At a given equilibrium concentration, the biomass takes up more metal ions at lower versus higher cell densities (Mehta \& Gaur, 2005). They suggested that electrostatic 
interactions between cells can be a significant factor in the relationship between biomass concentration and metal sorption. It can be seen that the biosorption capacity decreased from 70 and 50 to 16 and $8 \mathrm{mg} / \mathrm{g}$ for live and dead biomass, respectively, as the biomass concentration increased from 1 to $5 \mathrm{~g} / \mathrm{l}$. In this connection, Wang \& Chen (2006) reported that at a given metal concentration, the lower the biomass concentration in suspension, the higher will be the metal/ biosorbent ratio and the metal retained by sorbent unit, unless the biomass reaches saturation. They added that high biomass concentrations can exert a shell effect protecting the active sites from being occupied by metal. The result of this is a lower specific metal uptake.

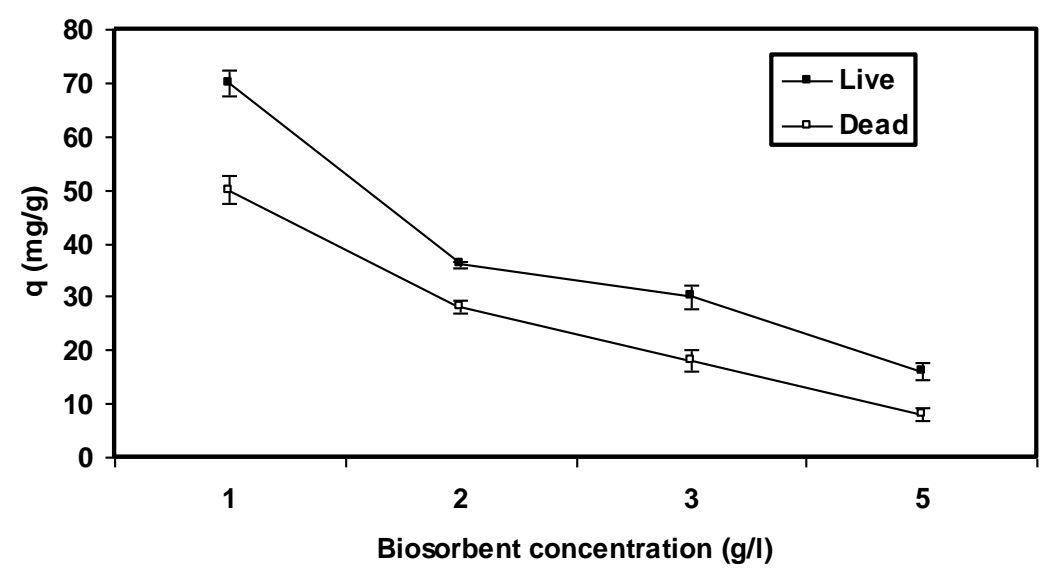

Fig. 11. Effect of biosorbent concentration (m) on $\mathrm{Cu}(\mathrm{II})$ uptake capacity of live and dead biomass of $A$. awamori. Biosorption conditions: $C_{i}=500 \mathrm{mg} / \mathrm{l} ; \mathrm{pH}=4.0$; $\mathrm{t}=30 \mathrm{~min}$ (for dead biomass) and 180min (for live biomass).

\section{Contact time}

The biosorption capacity of dead and live biomass as a function of contact time is presented in Fig. 12. It can be seen that the primary fast phase of biosorption by dead biomass occurred within the first $20 \mathrm{~min}$ and this was followed by second slow phase until equilibrium. A similar trend was observed (Wang et al., 2010). Equilibrium time was found to be $30 \mathrm{~min}$. On contrary, the rate of biosorption by live biomass was slow and reached the equilibrium within $180 \mathrm{~min}$. Metal ion uptake by yeast is known to involve an initial rapid phase (passive uptake), followed by much slower phase (active uptake). The first stage is physical adsorption or ion exchange at the surface of the biomass and accounted for the major part in total metal uptake, while the second one contributed to small part (Goyal et al., 2003). 


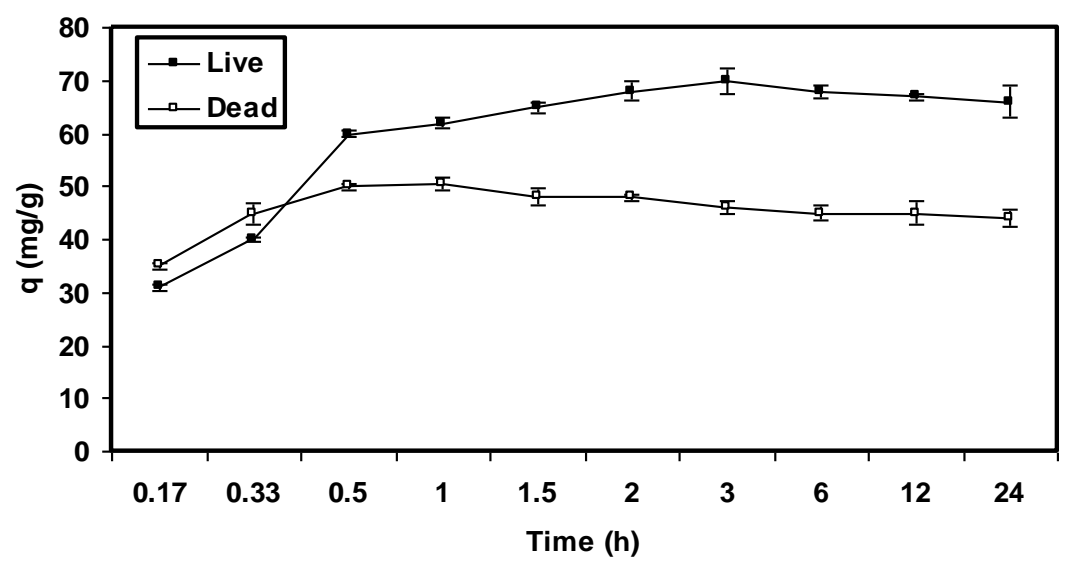

Fig. 12. Effect of contact time (t) on $\mathrm{Cu}$ (II) uptake capacity of live and dead biomass of A. awamori. Biosorption conditions: $C_{i}=500 \mathrm{mg} / \mathrm{l} ; \mathrm{m}=1 \mathrm{~g} / \mathrm{l}$ and $\mathrm{pH}=4.0$.

\section{FTIR spectroscopy}

One of the major challenges in knowing the chemical groups involved in biosorption is the complex nature of the microbial biosorbent material. The cell wall polymers provide a multitude of chemical groups such as hydroxyl carbonyl, carboxyl, sulhydryl, thioether, sulfonate, amine, imine, amide, imidazole, phosphonate and phosphodiester (Gupta \& Mohaptra, 2003). Volesky (1987) studied the chemical composition of the walls of $A$. niger and reported (\%) protein 8.3 ; chitin 8.3 ; chitosan 18.3 ; mannan 45.5 ; phosphate 11.5 and carbohydrate and lipids 8.1.

The FTIR spectra of native cells, $\mathrm{Cu}$ (II)-loaded live and $\mathrm{Cu}$ (II)-loaded dead cells in the range of 4000- $400 \mathrm{~cm}^{-1}$ is shown in Fig. 13a-c. There are some guide peaks in the spectra of the control which are helpful for achieving this goal (Fig. 13a). The position or the intensities of these peaks are expected to be changed upon the interaction of biomass with $\mathrm{Cu}(\mathrm{II})$; also new peaks and shoulders are found in the spectra of $\mathrm{Cu}$ (II)-loaded samples which gave an indicateion on chelation between oxygen-, nitrogen-, sulphur-, or phosphorus containing ligands of biomass with metal ions. A marked shift occurred in the wave number from 3402 to 3392 and $3400 \mathrm{~cm}^{-1}$ in live and dead $\mathrm{Cu}$ (II)- loaded biomass (Fig. 13b and c, respectively). Such shifts in the wave number and intensities of these peaks indicatee the interaction of $-\mathrm{NH}_{2}$ asymmetric stretch mode of amines and - $\mathrm{OH}$ groups with $\mathrm{Cu}$ (II) uptake. The changes in the intensities of peaks at $2926.5 \mathrm{~cm}^{-1}$ may be because of the interaction of $-\mathrm{CH}$ stretching vibrations of $-\mathrm{CH}_{2}-\mathrm{CH}_{2}$. Appearance of peak only in live $\mathrm{Cu}$ (II)loaded biomass at wave number $2356.6 \mathrm{~cm}^{-1}$ indicatee the involvement of aliphatic chain $-\mathrm{CH}$ in $\mathrm{Cu}$ (II) uptake by live biomass. The disappearance of peak at $2857 \mathrm{~cm}^{-1}$ in case of live $\mathrm{Cu}$ (II)-loaded biomass and the shift in the intensity by $3 \% \mathrm{~T}$ in the case of dead $\mathrm{Cu}$ (II)-loaded biomass may be because of the interaction of $-\mathrm{CH}$ stretching vibrations of $\mathrm{CH}_{2}-\mathrm{CH}_{3}$. After $\mathrm{Cu}$ (II) biosorption by live biomass, the peak at $1741.4 \mathrm{~cm}^{-1}$ is replaced by shoulder at $1730 \mathrm{~cm}^{-1}$, while in the case of dead biomass a 
slight shift occurred. These changes indicateed the interaction of carbonyl stretch of unionized carboxylates. A small shift of bands at $1637 \mathrm{~cm}^{-1}$ with a significant increase in the intensity after metal ion uptake can be attributed to $\mathrm{CO}$ stretching mode conjugated to $\mathrm{NH}$ deformation mode and an amide I band. A slight shift of band at $1550 \mathrm{~cm}^{-1}$ with an increase in the intensity was observed. This was the result of amide II and $\mathrm{NH}$ deformation mode conjugated to $\mathrm{C}=\mathrm{N}$ deformation mode. The marked shift at $1424 \mathrm{~cm}^{-1}$ for live $\mathrm{Cu}$ (II)-loaded biomass was indicateive of sulfonyl and sulfonamide groups. A small shift of bands at $1424 \mathrm{~cm}^{-1}$ was observed after $\mathrm{Cu}$ (II) uptake by dead biomass. The role of sulfonyl, sulfonamide groups and amide III can be observed again in the appearance of peaks in the wave number from 1372 to $1377 \mathrm{~cm}^{-1}$ after $\mathrm{Cu}$ (II) uptake by live and dead biomass. FTIR spectra of live biosorbent incurred more changes than dead, indicateing that more functional groups were involved in the biosorption process. The disappearance of bands being located at 1153 and $1151.3 \mathrm{~cm}^{-1}$ which are attributed to the loading of $\mathrm{Cu}(\mathrm{II})$ was explained by the involvement of $\mathrm{S}=\mathrm{O}$ stretching. Shifting of bands at $1081 \mathrm{~cm}^{-1}$ coupled with a sharp or significant decrease in the intensity and disappearance of bands at $1030.8 \mathrm{~cm}^{-1}$ may be due to the interaction of adsorbed metal with sulfoxides, $\mathrm{S}=\mathrm{O}$ stretching, sulfones, sulfonic acids and sulfonamides by live and dead biomass. Appearance of new bands after $\mathrm{Cu}$ (II) uptake by live and dead biomass at 865 and $860 \mathrm{~cm}^{-1}$, respectively indicateed the intervention of phosphorus and $\mathrm{P}=\mathrm{S}$ stretching in the process. The appearance of new bands at wave number ranging from 616.2 to $673.3 \mathrm{~cm}^{-1}$ and a marked shift at $588.2 \mathrm{~cm}^{-1}$ after uptake of metal ions is indicateive of C-S stretching. The role of C-S stretching appeared again in either a marked shift or disappearance of band at $449.3 \mathrm{~cm}^{-1}$ after metal ions uptake. Soft metals, such as $\mathrm{Hg}(\mathrm{II}), \mathrm{Cd}$ (II) and $\mathrm{Pb}$ (II) form stable bonds with nitrogen- and sulphur- containing (soft) ligands $\mathrm{CN}^{-}, \mathrm{R}-\mathrm{S}, \mathrm{SH}^{-}, \mathrm{NH}_{2}^{-}$and imidazole (Wang \& Chen, 2006). The greater the covalent index $\left(X_{m}^{2} r\right)$ (where $X_{m}$ is electronegativity and $r$ is the ionic radius), the greater its potential to form covalent bands with biological ligands, generally in the order: $\mathrm{S}>\mathrm{N}>0$ ( Chen \& Wang, 2007). Covalent index of $\mathrm{Cu}(\mathrm{II})=2.98$ (Brady \& Tobin, 1995). Li et al. (2013) reported that the FTIR analysis of Aspergillus sp.J2 indicateed that the sulfur compound was involved in $\mathrm{Se}(\mathrm{IV})$ biosorption.

\section{$X$ - ray diffraction analysis(XRD)}

To elucidate the chemical nature of $A$. awamori cell bound $\mathrm{Cu}(\mathrm{II})$, test biomass was subjected to XRD analysis before (control) and after $\mathrm{Cu}$ (II) sequestration (Fig. 14a-c). In contrast to untreated (control) biomass, which is expectedly amorphous (Fig. 14a), XRD spectra for live and dead biomass loaded with $\mathrm{Cu}(\mathrm{II})$ showed distinct reproducible patterns typical for the presence of crystalline materials (Fig 14b-c). Following $\mathrm{Cd}(\mathrm{II})$ and $\mathrm{Cu}$ (II) treatment, it was noticed that peaks in live biomass were more pronounced than these of dead one. The XRD pattern of $\mathrm{Cu}$ (II)-loaded live biomass (Fig. 14b) showed 28 peaks at $2 \theta$ ranging from 13.26 to $58.88 \mathrm{~A}^{\circ}$ and corresponding to respective $\mathrm{d}$-spacing from 6.68 to $1.57 \mathrm{~A}^{\circ}$. The XRD pattern of $\mathrm{Cu}$ (II)-loaded dead biomass (Fig. 14c) showed 23 peaks at $2 \theta$ ranging from 18.23 to $59.08 \mathrm{~A}^{\circ}$ and corresponding to respective $\mathrm{d}$-spacing from 4.87 to $1.56 \mathrm{~A}^{\mathrm{o}}$. Based on spacing d-values, these peaks after $\mathrm{Cu}(\mathrm{II})$ uptake are attributed to the presence of crystalline $\mathrm{Cu}(\mathrm{II})$ and $\mathrm{Cd}(\mathrm{II})$ sulphate hydrate; $\mathrm{CuSO}_{4} \cdot \mathrm{H}_{2} \mathrm{O}$. FTIR spectroscopic analysis of the tested Egypt. J. Microbiol. 48(2013) 
biomass also confirmed the involvement of sulfur-oxygen compounds in these metal ions uptake.
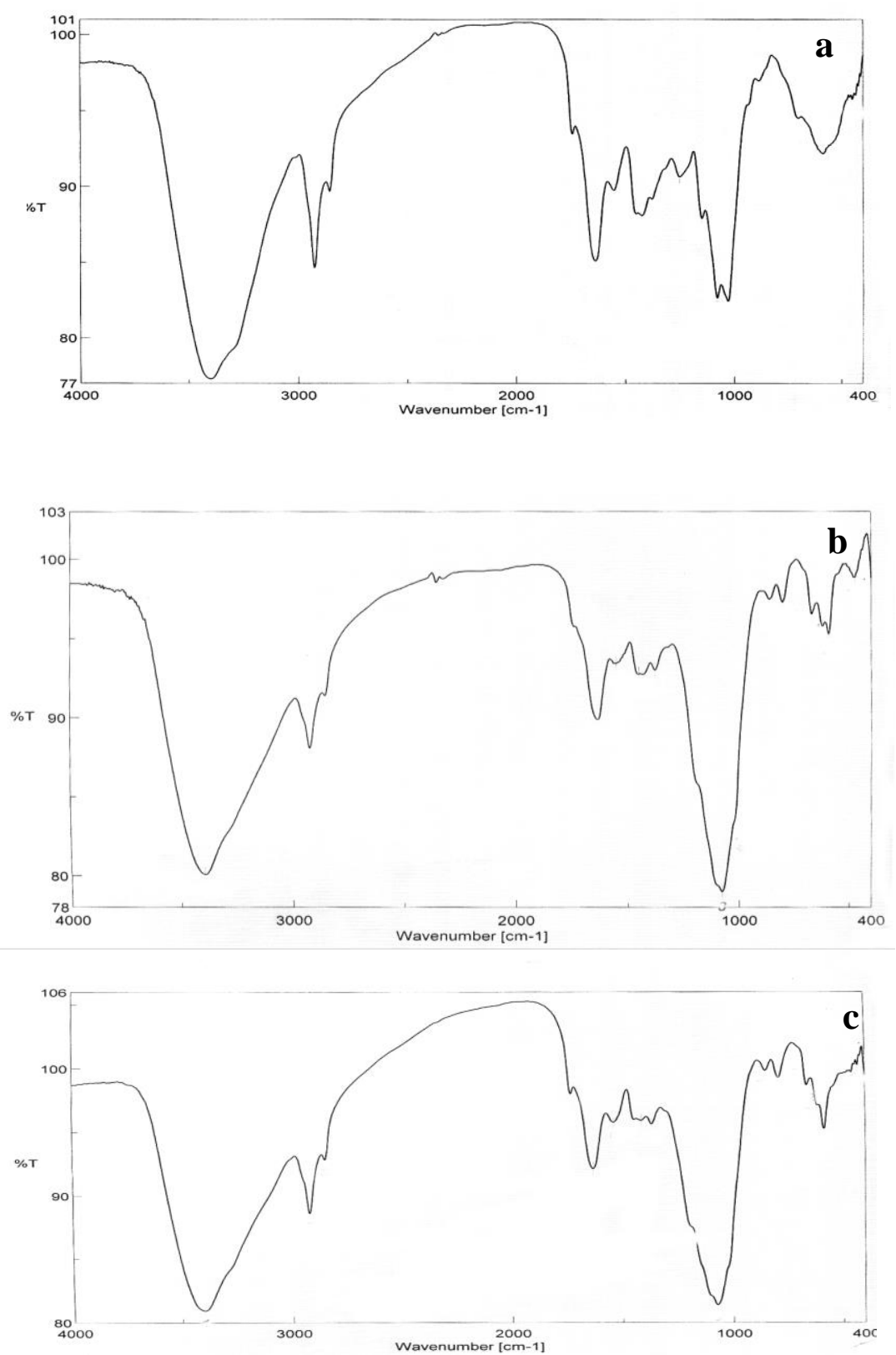

Fig. 13. FTIR spectra of A. awamori. (a) Native cells, (b) $\mathrm{Cu}(\mathrm{II})$ - loaded live cells, (c) $\mathrm{Cu}(\mathrm{II})$ - loaded dead cells. 


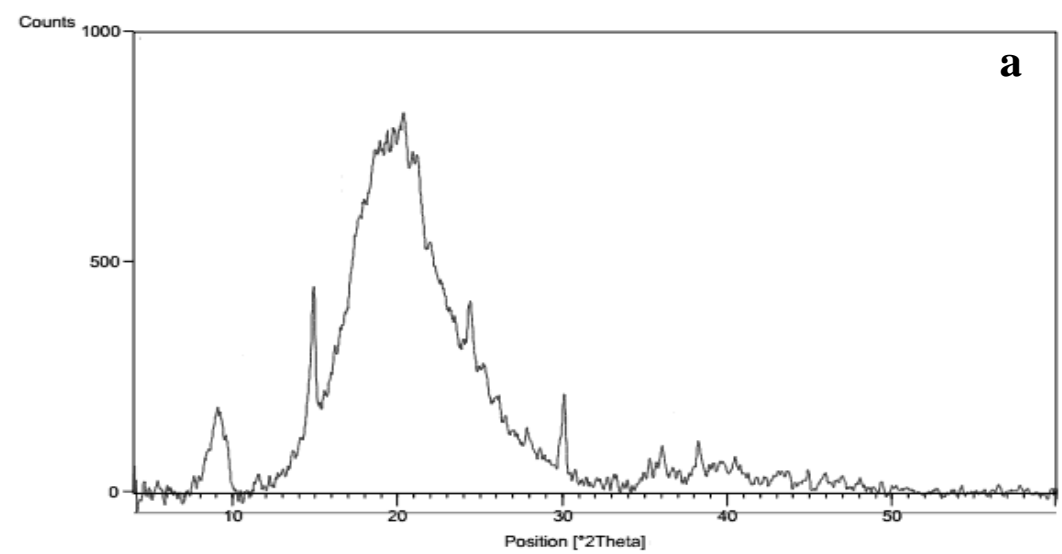

Counts
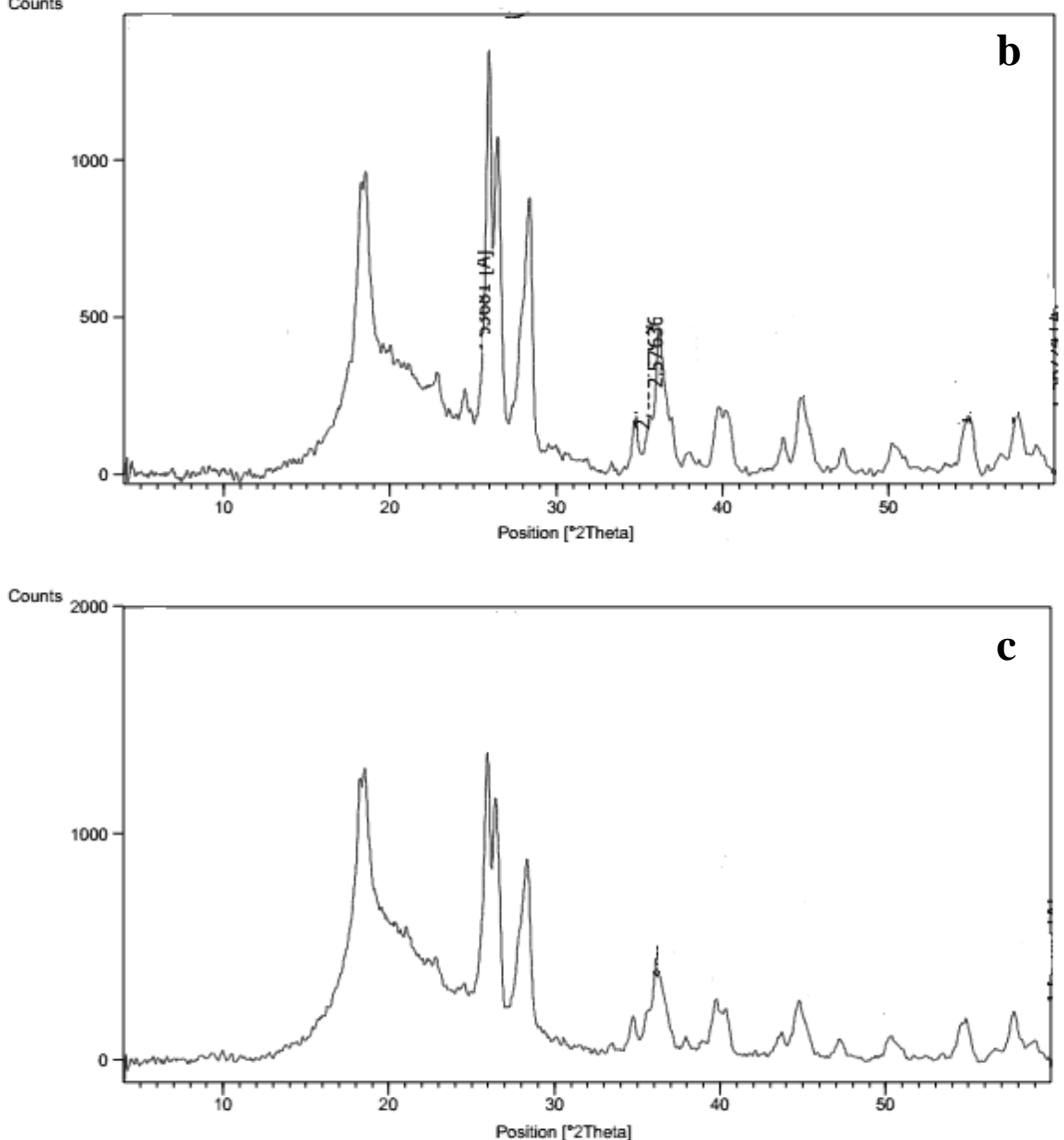

Fig. 14. XRD analysis of A. awamori. (a) Native cells, (b) $\mathrm{Cu}$ (II) - loaded live cells, (c) Cu(II) - loaded dead cells.

Egypt. J. Microbiol. 48(2013) 
Energy dispersive- $X$-ray microanalysis (EDAX)

EDAX analysis is based on the principle that $X$ - rays can be absorbed by matter, which gives rise to X-ray absorption spectra. These X-ray dispersion spectra may be detected at various angles that can then be co-related with the complex formed (Gupta \& Mohapatra, 2003). X-ray peaks showed a broadening in the peak full wave height maximum (FWHM) which confirmed the size of pellets of $\mathrm{CuSO}_{4} \cdot \mathrm{H}_{2} \mathrm{O}$ compounds. Also the height of the peak should be proportional to the weight percent of the compounds or their ingredients; $\mathrm{Cu}$ (II), $\mathrm{S}$ and $\mathrm{O}$. This bulk technique gives an elemental ratio of the population as a whole when analyzing the whole pellet following the metal exposure. EDAX spectra of $\mathrm{Cu}(\mathrm{II})$-loaded live and dead biomass showed distinct peaks for oxygen, sulfur and $\mathrm{Cu}(\mathrm{II})$ with element $\%$ 43.7, 6.1, 50.2, 67.02, 6.99 and 25.99, respectively. EDAX spectra of $\mathrm{Cu}$ (II)-loaded live and dead biomass (Fig. 15a and b) showed distinct peaks for oxygen, sulfur and $\mathrm{Cu}(\mathrm{II})$ with element $\% 53.56$, 11.36, 35.09, 72.29, 15.23 and 12.48, respectively. EDAX showed an excellent agreement with the corresponding FTIR and XRD analyses. FTIR indicateed the involvement of cellular sulfur-oxygen compounds in both metal ions binding. XRD analysis confirmed the presence of $\mathrm{CuSO}_{4} \cdot \mathrm{H}_{2} \mathrm{O}$ on live and dead biomass.
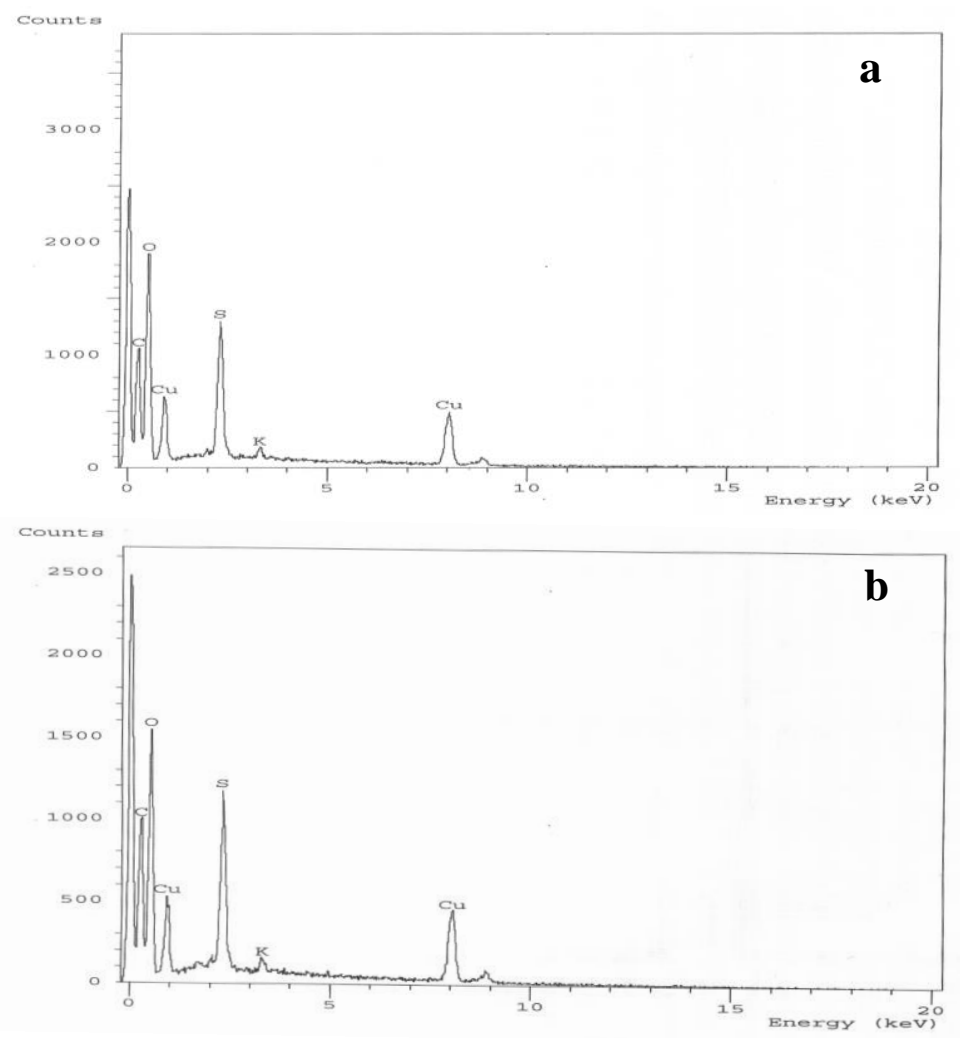

Fig. 15. EDAX microanalysis of A. awamori. (a) $\mathrm{Cu}$ (II) - loaded live cells, (b) $\mathrm{Cu}(\mathrm{II})$ loaded dead cells.

Egypt. J.Microbiol. 48 (2013) 


\section{References}

Ahmad, I., Imran, M., Ansari, M.I., Malik, A. and Pichtel, J. (2011) Metal tolerance and biosorption potential of soil fungi: Applications for a green and clean water treatment technology. In: "Microbes and Microbial Technology", I. Ahmad et al. (Ed.), pp. 321-361, Agricultural and Environmental Applications. Springer Science+Business Media LLC.

Ahmad, I., Ansari, M.I. and Aqil, F. (2006) Biosorption of Ni, $\mathrm{Cr}$ and Cd by metal tolerant Aspergillus niger and Penicillium sp. using single and multi- metal solution. Indian J. Exp. Biol. 44,73-76.

Ahonen-Jounarth, U., Roitlo, M., Markkola, A.M., Ranta, H. and Neuvonen, S. (2004) Effects of nickel and copper on growth and mycorrhiza of Scotspine abietina. For. Pathol. 34, 337-348.

Akar, T., Tunali, S. and Cabuk, A. (2007) Study on the characterization of lead (II) biosorpation by fungus Aspergillus parasticus. Appl. Biochem. Biotechnol. 136, 379406.

Akhtar, S., Mahmood-ul-Hassan, M., Ahmad, R., Suthor, V. and Yasin, M. (2013) Metal tolerance potential of filamentous fungi isolated from soils irrigated with untreated municipal effluent. Soil Environ.32(1),55-62.

Ali, E.H. (2007) Comparative study of the effect of stress by the heavy metals $\mathrm{Cd}(\mathrm{II})$, $\mathrm{Pb}$ (II) and $\mathrm{Zn}$ (II) on morphological characteristics of Saprolegnia delica Coker and Dictyuchus carpophorus Zopf. Polish. J. Microbiol. 56(4),257-264.

Babich, H. and Stotzky, G. (1980) Environmental factors that influence the toxicity of heavy metals and gaseous pollutants to microorganisms. CRC Crit. Rev. Microbiol. 8, 99-145.

Bahadir, T., Bakan, G., Altas, L. and Buyukgungor, H. (2007) The investigation of lead removal by biosorption: An application at storage battery industry wastewaters. Enzyme Microb. Technol. 41,98-102.

Bai, Z., Harvey, L.M., White, S. and McNeil, B. (2004) Effect of oxidative stress on production of heterologous and native protein, and culture morphology in batch and chemostat cultures of Aspergillus niger B1- D Enzyme. Microb. Technol. 34(1),10-21.

Baldrian, P. (2003) Interactions of heavy metals with white-rot fungi: Enzyme. Microb.Technol. 32,78-91.

Ban, Y., Tang, M., Chen, H., Xu, Z., Zhang, H. and Yang, Y. (2012) The response of dark septate endophytes (DSE) to heavy metals in pure culture. PloS ONE, 7(10), e 47968 .

Barata, R.M., Chapparro, A., Chabregas, S.M., Gonzalez, R., Labate, C.A., Azevado, R.A., Sarath, G., Lea, P.J. and Silva-Fiho, M.C. (2000) Targeting of the soybean legheemoglobin to tobacco chloroplasts : Effects on aerobic metabolism in transgenic plants. Plant Sci. 155,193-202.

Egypt. J. Microbiol. 48(2013) 
Bergmeyer, H.V., Gaulehn, K. and Grassl, M. (1974) In: "Methods of Enzymatic Analysis". Bergmeyer H .V. (Ed.), pp. 495- 496. $2^{\text {nd }}$ ed., Academic Press, New York, 1.

Binupriya, A.R., Sathishkumar, M., Kavitha, D., Swaminathan, K., Yun, S.E. and Mun, S.P. (2007) Experimental and isothermal studies on sorption of congo red by modified mycelial biomass of wood- ratting fungus. Clean, 35,143- 150.

Brady, J.M. and Tobin, J.M. (1995) Binding of hard and soft metal ions to Rhizopus arrhizus, biomass. Enzyme Microb. Technol. 17,791-796.

Burford, E.R., Hillier, S. and Gadd, G.M. (2006) Biomineralization of fungal hyphae with calcite $\left(\mathrm{CaCO}_{3}\right)$ and calcium oxalate mono- and dihydrate in carboniferous limestone microcosms. Geomicrobiol. J. 23, 599-611.

Chakraborty, S., Mukherjee, A. and Das, T.K. (2012) Biochemical characterization of a lead tolerant strain of Aspergillus foetidus: An implication of bioremediation of lead from liquid media. Int. Biodeterior. Biodegred. 84,134-142.

Chen, C. and Wang, J. (2007) Influence of metal ionic characteristics on their biosorption capacity by Saccharomyces cerevisiae. Appl. Microbiol. Biotechnol. 74, 911-917.

Clausen, C.A. and Green, F. (2003) Oxalic acid overproduction by copper- tolerant brown rot basidiomycetes on southern yellow pine treated with copper- based preservatives. Int. Biodeterior. Biodegrad. 51,139-144.

Ellman, C.L. (1959) Tissue sulfhydryl groups. Arch. Biochem. Biophys. 82,70-77.

Ferrol, N., Gonzàlez-Guerrero, M., Valderas, A., Benabdellah, K. and AzcónAguilar, C. (2009) Survival strategies of arbuscular mycorrhizal fungi in Cu-polluted environments. Phytochem. Rev. 8, 551-559.

Gadd, G.M. and White, C. (1989) Heavy metal and radionuclide accumulation and toxicity in fungi and yeasts, In: "Metal Microbe Interactions" Poole, R.K., Gadd, G.M. (Ed.). pp. 19-38. IRL Press, Oxford, UK.

Gams, W., Hoekstra, E.S. and Aptroot, A. (1998) In: "CBS Course of Mycology". Gams, W et al. (Ed.). $4^{\text {th }}$ ed. Centraalbureau voor Schimnelcultures, AG Baarn, the Netherlands.

Ge, W., Zamri, D., Mineyama, H. and Valix, M. (2011) Bioaccumulation of heavy metals on adapted Aspergillus foetidus. Adsorption, 17, 901-910.

Gochev, V.K., Velkova, Z.I. and Stoytcheva, M.S. (2010) Hexavalent chromium removal by waste mycelium of Aspergillus awamori. J. Serbian, Chem. Soc. 75(4), 551-564.

Gonzalez, G.M., Melville, L.H., Ferrol, N., Lott, J.N., Azoon, A. and Peterson, R.L. (2008) Ultra structural localization of heavy metals in the extraradical mycelium and 
spores of the arbuscular mycorrhizal fungus Glomus intrardices. Can. J. Microbiol. 54(2),103-110.

Goyal, N., Jain, S.C. and Banerjee, U.C. (2003) Comparative studies on microbial adsorption of heavy metals. Adv. Environ.7,311-319.

Green, F. and Clausen, C.A. (2001) Oxalic acid production of fifteen brown rot fungi in copper citrate treated southern yellow pine. IRG/ WP/O1-10388. International Research Group on Wood Protection Stockholm, Sweden.

Guelfi, A., Azevedo, R.A, Lea, P.J. and Molina, S.M.G. (2003) Growth inhibition of the filamentous fungus Apergillus nidulans by cadmium: An antioxidant enzyme approach. J. Gen. Appl. Microbiol . 49, 63-73.

Gupta, B.L. and Berridge, M.J. (1966) Fine structural organization of the rectum in the blowfly Calliphora erythrocephala (Meig) with special reference to connective tissue, trachea and neurosecretory innervation of the rectal papillae. J. Morphol. 120(1), 23-81.

Gupta, M., Mazumdar, U.K., Gomathi, P. and Kumar, R.S. (2004) Antioxidant and free radical scavenging activities of Ervatamia coronaria Stapf leaves. Iran. J. Pharm. Res. 2,119-126.

Gupta, R. and Mohapatra, H. (2003) Microbial biomass: An economical alternative for removal of heavy metals from waste water. Indian. J. Exp. Biol. 41, 945-966.

Gupta, V.K. and Rastogi, A. (2008) Biosorption of lead(II) from aqueous solutions by non live algal biomass Oedogonium sp. and Nostoc sp.- a comparative study. Colloids and Surfaces B: Biointerfaces, 64,170-178.

Hall, H. (2002) Cellular mechanisms for heavy metal detoxification and tolerance. J. Exp. Biol. 53,1-11.

Harley, M.M. and Freguson, I.K. (1990) "The role of SEM in Pollen Morphology and Plant Systematic”. Oxford University Press, Oxford, pp.45-68.

Hossain, A. and Kermasha, S. (1998) Inhibition of polyphenol oxidase activity by copper metallothionein, in polyphenol communications, XIXth International Electronic Conference on Polyphenols, Lille, France, v. 2, pp. 285-286.

Huang, F., Dang. Z., Guo, C., Lu, G., Gu, R.R., Liu, H. and Zhang, H. (2013) Biosorption of $\mathrm{Cd}$ (II) by live and dead cells of Bacillus cereus RC-1 isolated from cadmium contaminated soil. Colloids and Surfaces B: Biointerfaces, 107,11-18.

Issac, R. Suganya, M., Prabha, M.L. and Renitta, R.E. (2012) Biosorption of copper from electroplating effluent and its equilibrium studies. Int. J. Pharm Bio. Sci. 3(3),875-889.

Jarosz-Wilkolazka, A., Graz, M., Braha, B., Menge, S., Schlosser, D. and Krauss, G.J. (2006) Species- Specific Cd stress in the white rot basidiomycetes Abortiporus biennis and Cerrena unicolor. Biometals, 19, 39-49.

Egypt. J. Microbiol. 48(2013) 
Joner, E.J., Leyval, C. and Briones, R. (2000) Metal binding capacity of arbuscular mycorrhizal mycelium. Plant Soil, 226, 227-234.

Kapoor, A., Viraraghavan, T. and Cullimore, D. (1999) Removal of heavy metals using the fungus Aspergillus niger. Bioresour. Technol. 70,95-104.

Klaus-Joerger, T., Joerger, R., Olsson, E. and Granqvist, C.G. (2001) Bacteria as workers in live factory: Metal-accumulating bacteria and their potential for metals science. Trends in Biotechnol, 19(1),15-20.

Kumar, R., Bhatia, D., Singh, R. and Bishnoi, N.R. (2012) Metal tolerance and sequestration of $\mathrm{Ni}(\mathrm{II}), \mathrm{Zn}(\mathrm{II})$ and $\mathrm{Cr}(\mathrm{VI})$ ions from simulated and electroplating wastewater in batch process: Kinetics and equilibrium study. Int Biodeterior Biodegrad, 66, 82-90.

Li, Q., Harvey, L.M. and McNeil, B. (2009) Oxidative stress in industrial fungi. Crit. Rev. Biotechnol. 29(3), 199-213.

Li, Z.J., Li, H.F., Yang, X., Zhang, H., Liu, C. and Cao, B. (2013) Characterization of Se (IV) removal from aqueous solution by Aspergillus sp. J2. Chem. Eng. J. 20, 67-71.

Lowery, O.H., Rosenbrough, H.J., Faar, A.L. and Radnall, R. (1951) Protein measurement with the folin phenol reagent. J. Biol. Chem. 193, 263-275.

Luft, J.H. (1961) Improvements in epoxy resin embedding methods. J. Biophys. Biochem. Cytol. 9, 409-414.

Mehta, S.J. and Gaur, J.P. (2005) Use of algae for removing heavy metal ions from waste water: Progress and prospects. Crit. Rev. Biotechnol. 25,113-152.

Melo, R.G., Leitao, A.C. and Pàdula, M. (2004) Role of OGGI and NTGZ in the repair of oxidative DNA damage and mutagenesis induced by hydrogen peroxide in Saccharomyces cerevisiae: Relationships with transition metals iron and copper. Yeast, 21,991-1003.

Montazer-Rahmati, M.M., Rabbani, P., Abdolali, A. and Keshtkar, A.R. (2011) Kinetics and equilibrium studies on biosorption of cadmium, lead, and nickel ions from aqueous solutions by intact and chemically modified brown algae. J. Hazard Mater. 185, 401-407.

Nies, D.H. (1999) Microbial heavy-metal resistance. Appl. Microbiol. Biotechnol. 51,730750.

Osumi, M. (1998) The ultrasttructure of yeast: Cell wall structure and formation. Micron, 29, 207-233.

Palade, G.E. (1952) A study of fixation for electron microscopy. J. Exp. Med. 95(3), 285298. 
Pòesi, I. (2011) Toxic metal / metalloids tolerance in fungi- A biotechnology oriented approach. In: "Cellular Effects of Heavy Metals". Bànflavi, G. (Ed.) pp. 31-58. Springer Science+Business Media BV.

Poole, L.B., Karplus, P.A. and Claiborne, A. (2004) Protein sulfenic acids in redox signaling. Ann. Rev. Pharmacol. Toxicol. 44, 325-347.

Rathinam, A., Maharshi, B., Janardhanan, S.K., Jonnalagadda, R.R. and Nair, B.U. (2010) Biosorption of cadmium metal ion from simulated wastewater using Hypnea valentiae biomass: A kinetic and thermodynamic study. Bioresour Technol. 101,14661470 .

Reynolds, E.S. (1963) The use of lead citrate at high $\mathrm{pH}$ as an electron opaque stain in electron microscopy. J. Cell. Biol. 17,208-212.

Rothschild, L. and Mancinelli, R.L. (2001) Life in extreme. Environments. Nature, 409, 1092-1101.

Ruta, L., Paraschivescu, C., Matache, M., Avramescu, S. and Farcasanu, H.C. (2010) Removing of heavy metals from synthetic effluents using "Kamikaze" Saccharomyces cerevisiae cells. Appl. Microbiol. Biotechnol. 85,763-771.

Schmoger, M.E., Oven, M. and Grill, E. (2000) Detoxification of arsenic by phytochelatins in plants. Plant. Physiol. 122,793-801.

Soares, E.V., Hebbelinck, K. and Soares, H.M.V.M. (2003) Toxic effects caused by heavy metals in the yeast Saccharomyces cerevisiae: A comparative study. Can. J. Microbiol. 46,336-343.

Sptempack, J.G. and Ward, R.T. (1969) An improved staining for electron microscopy. J. Cell. Biol. 22,679-701.

Stephen, D.W. and Jamieson, D.J. (1996) Glutathione is an important antioxidant molecule in the yeast Sachharomyces cerevisiae. FEMS Microbiol. lett. 14(2-3),207212.

Tang, L., Zeng, G.M., Shen, G.L., Li, Y.P., Zhang, Y. and Huang, D.L. (2008) Rapid detection of picloran in agricultural field samples using a disposable immunomembrane-based electrochemical sensor. Environ. Sci. Technol. 42(2),12071212 .

Tsekova, K., Todorova, D. and Ganeva, S. (2010) Removal of heavy metals from industrial wastewater by free and immobilized cells of Aspergillus niger. Int. Biodeterior.\& Biodegrad. 64,447-451.

Varshney, V., Bhadauria, S. and Gaur, M.S. (2011) Biosorption of copper (II) from electroplating waste waters by Aspergillus terreus and its kinetics studies. Water 2,142-151.

Veglio, F. and Beolchini, F. (1997) Removal of metals by biosorption: A review. Hydrometallurgy, 44, 301-316.

Egypt. J. Microbiol. 48(2013) 
Velàsquez, L. and Dussan, J. (2009) Biosorption and bioaccumulation of heavy metals on dead and live biomass of Bacillus sphaericus. J. Hazard. Mater. 167,713-716.

Velkova, Z., Stoytcheva, M. and Gochev, V. (2012) Biosorption of $\mathrm{Cu}$ (II) onto chemically modified waste mycelium of Aspergillus awamori: Equilibrium, Kinetics and modeling studies. J. Biosci. Biotechnol. 1(2),163-169.

Vieira, R.H. and Volesky, B. (2000) Biosorption: A solution to pollution ? Inter. Microbiol. 3,17-24.

Vijayaraghavan, K. and Yun, Y.S. (2008) Bacterial biosorbents and biosorption. Biotechnol. Adv. 26, 266-291.

Viraraghavan, T. and Sirinivasan, A. (2011) Fungal biosorption and biosorbents. In: "Microbial Biosorption of Metals". Kotrba, P., Mackova, M., Macek, T. (Ed.), pp. 143-158. Springer Science+Business Media B.V.

Volesky, B. (1987) Biosorbents for metal recovery. Trends Biotechnol. 5, 96-101.

Volka, M., Morris, H. and Cronin, M.T.D. (2013) Metals toxicity and oxidative stress. Curr. Med. Chem. 13(10),1161-1208.

Wang, J. and Chen, C. (2006) Biosorption of heavy metals by Saccharomyces cerevisiae: A review. Biotechnol. Adv. 24,427-451.

Wang, J., Hu, X., Xie, S. and Bao, Z. (2010) Biosorption of uranium by immobilized $A$. fumigates beads. J. Environ. Radioact. 101(6),504-508.

Weishuang, Z., Yingheng, F. and Yi, H. (2009) Soluble protein and acid phosphatase exuded by ectomycorrhizal fungi and seedlings in response to excessive $\mathrm{Cu}$ and $\mathrm{Cd}$. $J$. Environ. Sci. 2, 1667-1672.

Xiao, X., Luo, S., Zeng, G., Wei, W., Wan, Y., Chen, L., Guo, H., Cao, Z., Yang, L., Chen, J. and Xi, Q. (2010) Biosoprtion of cadmium by endophytic fungus (EF) Microsphaeropsis sp. LSE10 isolated from cadmium hyper accumulator Solanum nigrum L. Bioresour .Technol. 101,1668-1674.

Yahya, M.I., Ezeh, G.C., Musa, Y.F. and Mohammed, S.Y. (2009) Analysis of heavy metals concentration in road sides soil in Yauri, Nigeria. Afr. J. Pure. Appl. Chem. 4(3), 22-30.

Zafar, S., Aqil, F. and Ahmad, I. (2007) Metal tolerance and biosorption potential of filamentous fungi isolated from metal contaminated agricultural soil. Bioresour. Technol. 98, 2557- 2561 


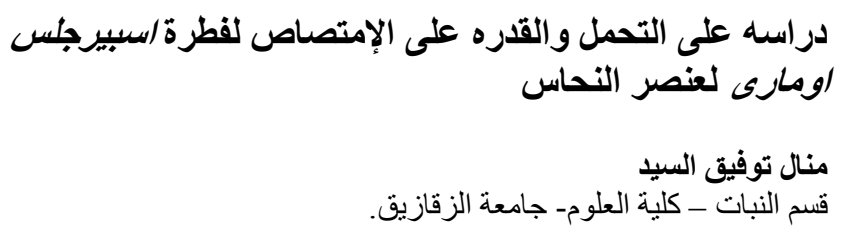

تم تعيين درجة التثبط الصغرى وكانت 3000 ملإيجرام/لتر وحدث تثبيط كامل

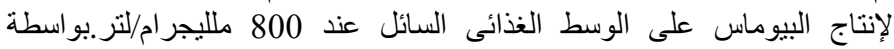

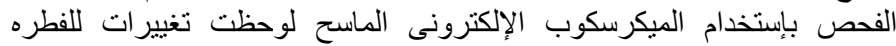

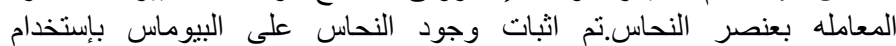

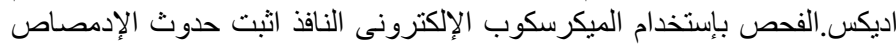

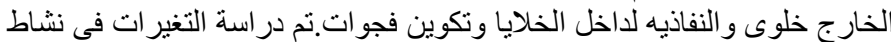

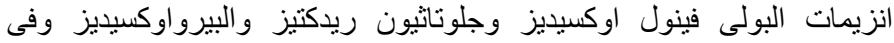

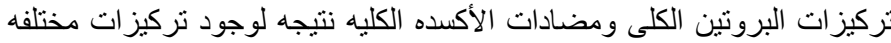

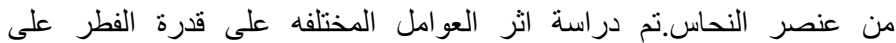
الإمنصاص.استخدمت تقنية FTIR,XRD,EDAX لمعرفة آلية الإمتصاص الثرل

لعنصر النحاس. 